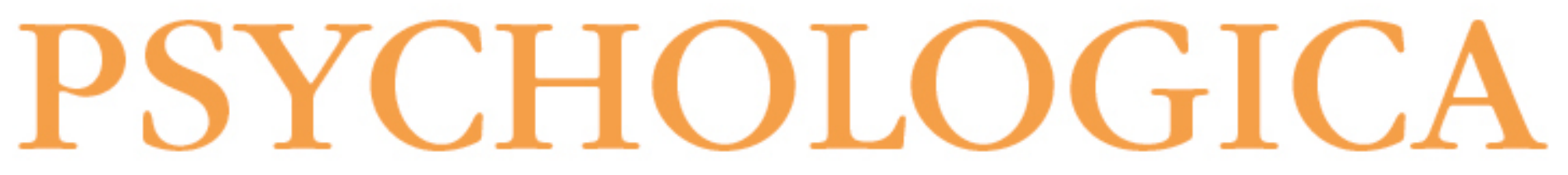

Etologia e psicologia evolutiva: perspectivas evolutivas para a psicologia clínica

Autor(es): $\quad$ Lencastre, Marina Prieto Afonso

Publicado por: Imprensa da Universidade de Coimbra

URL

persistente: URI:http://hdl.handle.net/10316.2/3445

DOI: $\quad$ DOI:http://dx.doi.org/10.14195/1647-8606_52-1_8

Accessed : $\quad$ 26-Apr-2023 09:31:08

A navegação consulta e descarregamento dos títulos inseridos nas Bibliotecas Digitais UC Digitalis, UC Pombalina e UC Impactum, pressupõem a aceitação plena e sem reservas dos Termos e Condições de Uso destas Bibliotecas Digitais, disponíveis em https://digitalis.uc.pt/pt-pt/termos.

Conforme exposto nos referidos Termos e Condições de Uso, o descarregamento de títulos de acesso restrito requer uma licença válida de autorização devendo o utilizador aceder ao(s) documento(s) a partir de um endereço de IP da instituição detentora da supramencionada licença.

Ao utilizador é apenas permitido o descarregamento para uso pessoal, pelo que o emprego do(s) título(s) descarregado(s) para outro fim, designadamente comercial, carece de autorização do respetivo autor ou editor da obra.

Na medida em que todas as obras da UC Digitalis se encontram protegidas pelo Código do Direito de Autor e Direitos Conexos e demais legislação aplicável, toda a cópia, parcial ou total, deste documento, nos casos em que é legalmente admitida, deverá conter ou fazer-se acompanhar por este aviso. 


\section{NÚMERO 52}

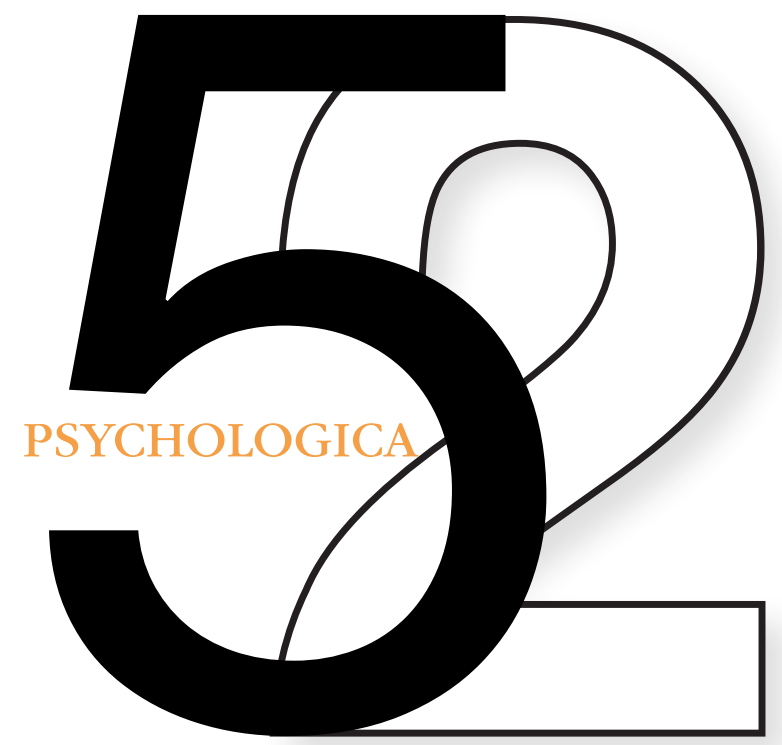

VOLUME I

IMPRENSA DA UNIVERSIDADE DE COIMBRA

FACULDADE DE PSICOLOGIA E DE CIÊNCIAS DA EDUCAÇÃO DA UNIVERSIDADE DE COIMBRA 


\title{
Etologia e psicologia evolutiva: perspectivas evolutivas para a psicologia clínica
}

\author{
Marina Prieto Afonso Lencastre' \\ A perspectiva evolutiva sobre o comportamento e o funcionamento mental permite \\ uma mais profunda compreensão e articulação dos seus aspectos, tanto normais \\ como patológicos. O presente artigo pretende fazer uma apresentação crítica de \\ aspectos da etologia cultural e da psicologia evolutiva que concorrem para uma \\ mais ampla e fundada apreciação das síndromas psicopatológicas e da psicologia \\ clínica. O evitamento do incesto é analisado nas suas vertentes biológicas, culturais, \\ sociais e psicológicas.
}

PALAVRAS-CHAVE: Evolução, Etologia cultural, Psicologia evolutiva, Psicopatologia, Limites da adaptação.

\section{Introdução}

O interesse pela perspectiva evolutiva aplicada à compreensão dos fenómenos psicopatológicos e à psicologia clínica conheceu um aumento importante durante a década de 90 do século passado e, com as novas descobertas sobre o funcionamento do sistema nervoso central, tem, neste século, servido como teoria de fundo para interpretar muitos aspectos da relação entre cérebro, mente e comportamento, tanto normal como patológico (Brune et al, 2003 por exemplo). A concepção do corpo e da mente humanos enquanto fenómenos biológicos não é nova; desenvolveu-se na Europa a partir dos anos 1930, com observações decisivas sobre o comportamento animal e, em 1970, conheceu importantes contribuições conceptuais por parte da biologia evolutiva, principalmente nos USA. A etologia animal e humana manteve-se próxima da observação e da descrição detalhada dos padrões comportamentais, considerando-os fenómenos adaptativos que deveriam ser compreendidos no interior da história evolutiva da espécie. A sociobiologia e, mais tarde, a psicologia evolutiva, acrescentaram a essas observações uma interpretação ecológica e genética que permitiu fazer

1 Professora Catedrática da Faculdade de Psicologia e das Ciências da Educação da Universidade do Porto e da Universidade Fernando Pessoa - mar_afonso@hotmail.com 
previsões sobre os comportamentos sociais, baseadas na ideia de que estes servem para a maximização reprodutiva (genética) dos indivíduos (ver à frente). 0 geneticismo da sociobiologia recebeu importantes críticas por parte dos cientistas sociais da época (Sahlins, 1976, por exemplo) e também por parte de evolucionistas actuais (Sloan Wilson, 2005, 2008, por exemplo), o que tem servido para temperar algumas propostas reducionistas e orientou também para um maior esforço de articulação interdisciplinar (Campbell, 1987, 1988; Lencastre, 1990 por exemplo), particularmente no caso das espécies socialmente mais complexas. A psicologia evolutiva, na sua pretensão de fornecer um quadro global de síntese para a psicologia, e nas referências que faz ao funcionamento modular do sistema nervoso central, tem recebido críticas importantes (Panksepp \& Panksepp, 2000 por exemplo). No entanto, estas perspectivas baseadas nos resultados da biologia do comportamento têm permitido lançar um olhar renovado e mais integrado sobre a psicopatologia e sobre a clínica, fornecendo modelos de observação, de interpretação e de previsão bastante fecundos.

Na psicologia clínica, a ideia de que os fenómenos psicopatológicos humanos seriam melhor compreendidos se fossem inseridos numa teoria biológica englobante, remonta ao fim do século XIX, com especial relevância para o trabalho inicial de Freud (Stevens \& Price, 2000). Mais tarde, Freud adoptou a interpretação psicológica do funcionamento mental, porque as suas concepções sobre a evolução das espécies como modelo para o desenvolvimento psicossexual não encontraram eco na biologia evolutiva da época ou mesmo na biologia posterior (Webster, 2002)2. Por outro lado, a etologia não tinha ainda fornecido as suas primeiras observações sobre as homologias comportamentais, a relação herdada entre estímulos e mecanismos desencadeadores das respostas, a constância e precocidade dos períodos críticos e do imprinting, a existência de ordem social e de ritualizações na comunicação animal e humana. Estas observações começaram a ser feitas de modo sistemático a partir de 1930, altura em que Freud já tinha elaborado os aspectos principais da psicanálise. A dimensão filogenética humana ficou assim reduzida aos «resíduos arcaicos» da mente e a um inconsciente cultural mal definido, cuja descendência Freud imputava a mecanismos lamarckianos de transmissão das informações culturais.

A dimensão filogenética da mente aplicada à psicopatologia foi desenvolvida de modo mais sistemático por C.G.Jung, um dos discípulos de Freud que divergiu do mestre em pontos essenciais, como a concepção sexual do funcionamento

\footnotetext{
2 Freud baseou-se na concepção de Fliess sobre a bissexualidade infantil, cuja organização por estádios se inspira, por sua vez, na teoria da recapitulação de Haeckel (Webster, 2002).

3 Sobre a recuperação da ideia lamrackiana da transmissão dos caracteres adquiridos ver mais à frente os trabalhos sobre epigenética de Mc Gowan et al, 2008 e Handel e Ramagopalan, 2010, por exemplo.
} 
psíquico e a tónica posta sobre a história da espécie, em detrimento da história individual. Para Jung, a mente estrutura-se tanto sobre os arquétipos herdados da história da humanidade - estruturas emocionais e motivacionais poderosas, reconhecíveis nos símbolos - como sobre as histórias individuais, onde os arquétipos se actualizam. Assim, um comportamento ou um pensamento, investidos emocionalmente, carregam tanto a predisposição inata para agir e para pensar de determinadas maneiras, como as situações particulares em que tomam forma concreta na vida da pessoa (Jung, 2002; Stevens, 2002).

A concepção dinâmica dos arquétipos aproxima-se da concepção orientada dos padrões comportamentais, tais como os define a etologia e, segundo Stevens (2002), contém também a vertente adaptativa de longo prazo proposta pela psicologia evolutiva. No entanto, apesar de ter reconhecido o parentesco entre a sua definição de arquétipo e a definição de instinto dada pela primeira etologia objectivista (Jung, 2002), Jung manteve uma interpretação psicológica e cultural da mente. O inconsciente colectivo, de onde provêm os arquétipos, é um inconsciente cultural, mesmo se o seu funcionamento se aproxima do funcionamento intencional dos instintos.

Na psicologia clínica, a concepção filogenética do comportamento e da mente normal e patológica recebeu uma outra importante achega com o trabalho de J. Bowlby, durante a década de 1960. Baseando-se nas observações de Harlow $(1958,1965)$ sobre os efeitos da separação precoce da cria e da mãe do macaco rhesus, Bowlby defendeu que a vinculação à mãe da cria de primata e, portanto, também do bebé humano à sua mãe, depende mais de factores inatos do que da aprendizagem. Com esta teoria, Bowlby destronou para sempre as ideias reinantes na psicologia da época de que os bebés se ligam às suas mães através de condicionamento operante, cujo estímulo incondicional é o alimento. Mas mesmo se Bowlby se baseou na etologia para fundamentar as suas conclusões e, mesmo se, na continuação do seu trabalho, se referiu consistentemente à teoria da evolução para explicar o funcionamento e os disfuncionamentos do mecanismo da vinculação, a psicologia do desenvolvimento manteve-se mais atenta aos factores próximos, como as relações precoces entre pais e filhos, e descurou em grande parte os factores distantes, como a evolução e a função adaptativa desses mesmos comportamentos. De facto, adoptar uma perspectiva evolutiva e adaptativa sobre a vinculação permite considerar, de modo integrado, os factores próximos e os factores distantes (Tinbergen, 1963). Ela considera a) a relação com os genes que estão na base da sua expressão comportamental, b) a importância funcional que apresenta em ecologias típicas da evolução das relações parentais no contexto da organização dos grupos familiares nos primatas humanos e não humanos, c) os factores epigenéticos ligados ao desenvolvimento e à aprendizagem e d) os circuitos neuropsicológicos envolvidos. 
A consideração dos factores próximos de causalidade, como os processos de desenvolvimento e a neuropsicologia envolvida, assim como a consideração dos factores distantes, como a evolução etológica e a sua função em ecologias físicas e sociais específicas, aumenta as possibilidades de compreensão dos comportamentos normais e também das síndromas psicopatológicas, aumentando igualmente as possibilidades de intervenção terapêutica. Um dos aspectos interessantes da clínica de inspiração evolutiva, frequentes vezes apontado pelos autores desta área (Sloman \& Gilbert, 2000; Gilbert \& Bailey, 2000, por exemplo), consiste na sua capacidade em integrar diversas modalidades terapêuticas que, tradicionalmente, pertencem a escolas opostas. Assim, a intervenção pode a) ser genética (tendo em conta as delicadas questões colocadas pelo polimorfismo populacional e também pela epigenética; ver Wilson, 2006; McGowan et al, 2008; Brune, 2008; Handel \& Ramagopalan, 2010), b) ela pode ser psicodinâmica e consistir numa interpretação selectiva dos comportamentos e emoções que visa reconduzi-los às condições ecológicas e funcionais (interpessoais) em que se manifestaram, c) ela pode focar os factores de desenvolvimento com a existência de períodos críticos de aprendizagem emocional e cognitiva, e, finalmente, d) pode ser psicofarmacológica e neuropsicológica. Cada modalidade de intervenção será avaliada em função da sua pertinência clínica, e esta última resultará de uma compreensão alargada do significado evolutivo dos comportamentos, pensamentos e emoções. Assim, o que aparece como patológico poderá corresponder a uma vantagem selectiva na situação actual (a depressão, por exemplo; ver Lencastre, 2009), ou pode exprimir um comportamento que foi funcional numa ecologia passada (certas fobias, por exemplo; ver Stevens \& Price, 2000). Pode também manifestar o efeito de um polimorfismo genético com efeitos ecológicos (a esquizofrenia, por exemplo; ver Brune, 2008), pode ser o resultado epigenético de uma modificação no funcionamento neuroquímico, resultado de condições de desenvolvimento alteradas, nesta ou em gerações anteriores (stress materno intergeracional, por exemplo; ver McGowan, 2008).

É de notar ainda que uma abordagem integrada deste género torna compatíveis, debaixo de uma só teoria, diversas intervenções psicoterapêuticas tais como a cognitivo-comportamental, a sistémica ou a psicodinâmica, dependendo dos níveis a que se pretenda agir. De facto, a perspectiva evolutiva sobre a psicopatologia aparece como uma teoria integradora de diversas abordagens (Sloman \& Gilbert, 2000) que são relativas a diversos níveis funcionais. Aceitando explicitamente a herança biológica mas também a plasticidade epigenética do desenvolvimento, que inclui a aprendizagem dos estímulos sócio-culturais, particularmente durante os períodos críticos, a abordagem evolutiva articula biologia e culturas, genes, epigénese e aprendizagem. Compreender o comportamento humano, e as suas disfunções, implica assim perceber como se fazem os percursos individuais a 
partir de biologias específicas, em contextos ecológicos, etnológicos, familiares e individuais particulares.

\section{Pequena história da biologia do comportamento e da psicolo- gia evolutiva}

\section{a. Etologia e psicologia comparada}

A etologia, no seu sentido mais lato, representa o estudo biológico do comportamento. Historicamente, o termo foi criado por Geoffrey Saint-Hilaire em 1851 e designava, por esta palavra, o que Haeckel, igualmente um importante biólogo do século XIX, chamava então de ecologia: o estudo das condutas animais nas condições do meio natural.

No entanto, os primeiros estudos sobre o comportamento vindos da zoologia só se realizaram verdadeiramente, e em condições independentes, por três naturalistas do início do século XX, que foram Julian Huxley na Grã-Bretanha, Oscar Heinroth na Alemanha e Charles Whitman, nos Estados Unidos. Enquanto a maior parte dos zoólogos dos finais do século XIX se preocupava sobretudo em resolver questões fundamentais da sistemática, da fisiologia e da biologia do desenvolvimento, estes autores debruçaram-se sobre a conduta, atitudes e movimentos dos vertebrados, constatando que estes são próprios a cada espécie e diferem de uma para a outra, podendo ser utilizados como indicadores taxonómicos tão fiáveis como os caracteres morfológicos.

Estava assim apontada uma das características básicas da etologia: a de que o comportamento é tão específico da história evolutiva da espécie, como o são os indicadores morfológicos utilizados pela zoo-sistemática. O comportamento é, assim, o resultado de um processo funcional inscrito no genótipo e actualizado por cada membro da espécie. Com a teoria da selecção natural de Darwin, que foi exposta na obra On the Origin of Species (1859), sabia-se que a forma, a coloração e os diferentes índices biométricos dos segmentos animais, se tinham estabilizado na evolução através da selecção, ou seja, através da transmissão aos descendentes das características que se revelaram úteis para a sua sobrevivência. As características francamente desvantajosas perdiam-se na história da espécie, através do desaparecimento sem descendência.

Com Darwin e a sua teoria da evolução estavam criadas as condições para o surgimento da etologia como teoria e como método. O próprio Darwin foi precursor da abordagem biológica do comportamento com a sua obra The expression of emotions in man and animals (1872). Da obra de Darwin nasceram as orientações 
para a etologia e para a psicologia comparada, que trata de determinar quais as semelhanças e quais as diferenças entre os animais e os humanos, através de metodologias de laboratório que controlam experimentalmente as características que se pretendem estudar.

154 É, no entanto, contra uma versão artificiosa do estudo do comportamento em laboratório, representada sobretudo pelo behaviorismo clássico, que se organiza a etologia, nomeadamente a partir dos anos trinta do século XX, através da obra de Konrad Lorenz (1905-1989). Este médico e zoólogo vienense, tido como o pai da etologia enquanto ciência, foi o fundador efectivo da etologia comparativa através da utilização sistemática dos seus princípios teóricos e metodológicos. A observação do animal no seu habitat natural, a consideração da sua história evolutiva e adaptativa, o interesse pela função e causalidade dos comportamentos, tornaram-se característicos desta abordagem, nomeadamente a partir das propostas de Tinbergen (1963) sobre os factores distantes e os factores próximos que condicionam a expressão comportamental. Outros conceitos, como os padrões motores fixos - os antigos instintos - e a sua inscrição no património genético, os estímulos desencadeadores inatos, as actividades deslocadas e as actividades vazias, resultaram, no caso de Lorenz, numa valorização substancial da hereditariedade em detrimento da aprendizagem. Este 'inatismo' de Lorenz foi muito criticado, nomeadamente pelos cientistas sociais da época, que rejeitaram o que parecia um determinismo biológico difícil de aceitar para os comportamentos humanos. A questão recebeu uma resposta mais ponderada, derivada dos próprios trabaIhos de Lorenz sobre o imprinting sexual. A observação e as experiências sobre o imprinting mostraram a existência de períodos criticos precoces na ontogenia animal, em que a exposição a determinados estímulos bem definidos se torna fundamental para o normal desenvolvimento do reconhecimento intra-específico e, mais tarde, do comportamento sexual. Ao lado de Lorenz surgiram também Nikolaas Tinbergen, com importantes contribuições sobre o comportamento social dos animais, e Karl Von Frisch, com trabalhos sobre a linguagem dançada das abelhas, interpretada no âmbito da organização da colmeia. A atribuição, em 1973, do Prémio Nobel a estes três autores, consagrou definitivamente a etologia como disciplina científica.

O período fundador da etologia foi europeu, principalmente austríaco e alemão, com o estabelecimento de observações fundamentais relativas às hierarquias, agressão e territorialidade animais (Schjelderup-Ebbe, 1922; Lorenz, 1963; Klopfer, 1966; Moyer, 1968)4, às exibições rituais, nupciais ou agonistas (Huxley, 1914, 1966; Wickler, 1970; Eibl-Eiblesfeldt, 1970), à comunicação animal e aos fundamentos

4 Estas e as outras referências que se seguem constituem somente alguns exemplos do imenso trabalho de investigação e de publicação na área da etologia animal e humana. 
neurofisiológicos do comportamento (Busnel, 1963; von Holst 1969). Durante esta primeira fase, a etologia associou-se às preocupações epistemológicas típicas do pensamento europeu sobre a relação entre o organismo, o comportamento e a subjectividade, tendo dado origem a obras experimentais fundamentais como a fenomenologia biológica de Buytendijk (1958) e de Thinès (1966, 1975, 1977, 1991), assim como a reflexões sobre o que poderia constituir uma extrapolação dos métodos objectivistas para a compreensão do comportamento humano (Lencastre, 1990). É também na Alemanha e, mais tarde, em Inglaterra, que nasce a etologia humana, nesta fase estreitamente ligada à antropologia e à psicologia (Eibl-Eibesfeldt, 1989). R. Hinde $(1970,1991)$ consolidou a nova área da etologia humana através da fundamentação da sua relação com a psicologia, e a primatologia forneceu as primeiras observações sobre os comportamentos dos chimpanzés em liberdade (Goodall, 1971, 1986). Mais adiante, a etologia cultural (Thinès, com. pessoal; Lestel, 2004) consistiu numa tentativa de conciliar a abordagem evolutiva dos comportamentos humanos com a singularidade dos significados culturais, amplamente manifestados pelos estudos em antropologia. A psicoetologia (Ades, 1986; Bussab, 1998) consiste, por sua vez, na tentativa de conciliar o estudo biológico do comportamento com a actividade psicológica. A etologia cognitiva nasceu na década de 1980 e associou-se, na década de 1990, à neurobiologia e a uma crescente compreensão do funcionamento cerebral em ligação com os grupos sociais e com o meio ambiente (Camhi, 1984; Smuts, 1987; Ristau, 1991; Dunbar, 1992; Bekoff \& Jamieson, 1996; Moss \& Shettleworth, 1996). A etologia da década de 1980 também se associou ao pensamento epistemológico sobre os limites da ciência, particularmente evidentes no reducionismo potencial das modelizações da biologia evolutiva (Lencastre, 1990, 1999) e, mais tarde, da sociobiologia.

Em geral, a etologia interessa-se pela observação e descrição minuciosa dos comportamentos individuais, mesmo se inseridos num grupo e num dado biótopo. Ela apresenta um grande interesse metodológico, como tem sido comprovado pelos importantes resultados da recente primatologia (Smuts, 1987; Goodall, 1990; Tomasello, 1999; Wrangham, 2009) na compreensão dos factores de hominização e de aspectos centrais do comportamento social, como a teoria da mente e a empatia social (Byrne, 1988, 1987; de Waal, 1982, 1995, 1996, 2006, 2008), ou a origem da linguagem (Dunbar, 1996; Deacon, 1997; Tomasello, 2003). Por sua vez, a etologia cognitiva tem permitido compreender o funcionamento de outras mentes e a sua ligação com o cérebro, fornecendo dados importantes para a análise da relação mente-cérebro humanos (Ghazanfar \& Hauser, 1999; Zupanc, 2004; Platt \& Ghazanfar, 2010). A etologia humana e, mais recentemente, a etologia cultural (Thinès, op. Cit.) e a psicoetologia (Ades, Bussab, op. Cit.) mantêm-se próximas da antropologia e da psicologia e permitem compreender os modos 
como a unidade biológica da espécie humana produz a variedade psicológica e as manifestações normais e patológicas, nas culturass. A visão bio-antropológica, e o interesse que a etologia mantém pelos comportamentos individuais, torna-a particularmente interessante para a clínica e para a compreensão das disfunções mentais e comportamentais. Assim, por exemplo, a capacidade comum aos antropóides e aos humanos para atribuírem estados mentais aos congéneres, e para agirem socialmente em função da interpretação que deles fazem (Whiten \& Byrne, 1997), poderá estar afectada nos delírios paranóides de ciúme e de desconfiança persecutória (Kinderman, 2003). De facto, estes delírios dizem respeito a possibilidades da vida social dos humanos, que se estrutura amplamente sobre as relações sócio-sexuais e as suas motivações. Neste contexto, e por comparação, a hipótese do déficit na atribuição de estados mentais é mais dificilmente aplicada à compreensão dos delírios esquizofrénicos, cujo conteúdo parece não apresentar valor funcional evidentemente a daptativo à vida social, mas apresentase como lacunar e desorganizado relativamente aos contextos sociais e mesmo físicos (Ibidem). Esta característica levou Stevens e Price (2000) a considerarem a esquizofrenia como uma patologia mental mais recente em termos evolutivos, que envolve sobretudo as áreas corticais que processam a informação perceptiva e cognitiva e cuja desorganização poderá resultar de uma sobreactivação de certas zonas perceptivas e /ou da linguagem, e de uma incapacidade do cérebro humano moderno para integrar esses níveis elevados de actividade (ver também Wible et al, 2009). Estes exemplos mostram toda a importância da observação minuciosa dos comportamentos e da compreensão da sua funcionalidade etológica, em contextos particulares (Lencastre, 2009).

\section{b. Sociobiologia e a genética do comportamento social}

Em 1970, o etólogo inglês J. Crook criticou a abordagem individualista da etologia, argumentando que ela deveria interessar-se pelos comportamentos sociais tais como estes se organizam dinamicamente no seio dos grupos. Na mesma altura, o entomologista norte-americano $\mathrm{E} O$. Wilson publicou a sua influente obra sobre sociobiologia (1975), onde apresenta os princípios gerais de uma nova síntese entre etologia, genética e ecologia, que se interessa principalmente pela dinâmica adaptativa dos comportamentos sociais. A sociobiologia foi muito influenciada pelos trabalhos de Hamilton $(1963)$ e de Trivers $(1972,1974)$ sobre a modelização do "egoísmo" e do "altruísmo» ${ }^{6}$ nos grupos reprodutivos e permitiu fazer, pela

\footnotetext{
5 Associando-se, potencialmente, à etnopsiquiatria.

6 Mais raramente poderão adoptar a ploiginandria, como é o caso do marsupial nocturno australiano da espécie Trichosurus caninus.
} 
primeira vez, previsões sobre os comportamentos sociais, em situações de interacção concretas. O desenvolvimento, enquanto sociobiologia, da teoria darwiniana, com a aplicação de modelos matemáticos incluindo factores genéticos (como o grau de parentesco) e factores ecológicos (como o acesso a recursos) deslocou a tónica explicativa do nível do indivíduo para o nível da genética comportamental e para o nível da ecologia do comportamento. Mas apesar da relevância empírica de algumas das teorias parciais da sociobiologia, como a teoria do sucesso inclusivo, a teoria do investimento parental ou a teoria da selecção sexual, esta disciplina apresenta sobretudo um carácter exploratório quando se trata de compreender comportamentos sociais mais sofisticados e mediados por cérebros complexos, como é o caso do ser humano.

A sociobiologia tem como axioma de base o fundamento genético dos comportamentos sociais. A ideia consiste em aceitar que estes comportamentos foram seleccionados ao longo da evolução porque permitiram que os seus portadores sobrevivessem e se reproduzissem mais do que outros variantes (genéticos). Esta 'nova síntese' das ideias darwinianas consiste, portanto, em interpretar os comportamentos sociais a partir do sucesso evolutivo, que é medido em função das taxas de sobrevivência e de reprodução dos genes que estão na base desses mesmos comportamentos sociais. Uma vez que estes comportamentos e os seus genes são herdados, eles persistem nos organismos actuais e condicionam as suas motivações sociais. O comportamento materno, por exemplo, é explicado como tendo sido seleccionado por causa do valor de sobrevivência que representou para os filhos e para a transmissão, através deles, dos genes da linhagem materna até às gerações futuras.

Como é patente, o critério que preside a esta análise das motivações sociais é genético, na linha inaugurada por Hamilton (1963) e por Trivers (1972, 1974), acima citados para a explicação dos comportamentos «egoístas» e «altruístas». A cooperação e o "altruísmo» são fenómenos correntes no mundo animal que, através da análise genética encontraram uma explicação evolutiva satisfatória. De facto, contradizendo aparentemente a ideia darwiniana de competição egoista por recursos alimentares e sexuais, a cooperação e o «altruísmo» biológico, genericamente definido como o sacrifício de um animal em favor de outros, coloca um sério dilema à biologia evolutiva: como pode ser evolutivamente adaptativo sacrificar-se em favor de outros e assim correr o risco de condenar o seu próprio potencial reprodutivo?

O trabalho moderno sobre cooperação e «altruísmo» resolveu esta questão através da introdução, em 1963, por W.D.Hamilton, do conceito de vantagem inclusiva (inclusive fitness). Este autor argumentava que os comportamentos cooperativos e altruístas tinham evoluido com mais probabilidade entre animais aparentados do 
que entre animais sem parentesco. Os parentes partilham mais genes semelhantes do que os não aparentados, o que significa que uma acção beneficiando um parente reverte a favor do altruísta, na medida em que a probabilidade de reprodução dos genes comuns foi aumentada pelo acto altruísta. Assim, o «altruísmo» biológico consiste num «egoísmo" genético. A teoria de Hamilton baseia-se numa modelo matemático complexo que prevê que a cooperação deverá ser mais frequente entre animais aparentados do que entre os não aparentados, e que o grau de "altruísmo» dependerá do grau de parentesco genético. A sua teoria, associada ao trabalho de E.O.Wilson sobre os insectos sociais, forneceu um contexto muito favorável para o desenvolvimento da sociobiologia e das suas hipóteses sobre a origem filogenética do "altruísmo". Dado que o parentesco estabelece homologias genéticas de vários graus, também o comportamento se verá afectado com vários tipos de motivações sociais: assim, o «altruísmo» (genético) consiste em ajudar os parentes, mesmo com prejuízo próprio. De facto, o indivíduo passa os seus genes para as gerações futuras através do investimento no comportamento reprodutivo dos seus parentes. Do mesmo modo, o "egoísmo» consiste no aproveitamento dos outros (aparentados ou não) em próprio favor, ou seja, em favor do seu potencial reprodutivo (genético). A «malevolência» arrasta o prejuízo dos outros, sem proveito (genético) necessário para si, mas com diminuição do potencial dos outros. Finalmente, a cooperação, ou «altruísmo» recíproco (ou condicional), consiste em ajudar os outros não a parentados, com proveito genético também (ver à frente).

A correlação entre a quantidade de comportamento "altruísta» ou «egoísta» e o grau de partilha genética, permitiu explicar de modo quantitativo certos comportamentos animais incompreensíveis como, por exemplo, o infanticídio pelos machos recém-chegados a haréns (o caso dos leões), ou ainda o infanticídio pelas fêmeas (de roedores, por exemplo), e também a reabsorpção fetal. No caso dos leões, o assassinato das pequenas crias de um rival predecessor tem como consequência a entrada no cio da leoa e, portanto, a possibilidade de produzir uma nova ninhada com os genes do leão recém-chegado. O infanticídio pelas fêmeas de roedores justifica-se pelas limitações ecológicas (recursos territoriais, alimentares, reprodutivos diminuídos) e pelo adiamento da reprodução para uma época mais propícia. A reabsorpção fetal observa-se quando a fêmea de roedor gestante é exposta à presença e, provavelmente, à influência hormonal, de um outro macho, que não é o progenitor dos seus embriões. O bloqueio da gravidez parece ser devido ao stress provocado pela presença do macho estrangeiro e é mediado pelos efeitos neuroimunológicos sobre a actividade da prolactina (Baines et al, 1994). A reabsorpção evita um investimento fisiológico importante em crias cujas condições de sobrevivência são postas em causa pelo novo companheiro da fêmea.

A teoria do investimento parental, que suporta a explicação sociobiológica destes comportamentos, mostra que os pais estão dispostos a investir nos seus filhos e 
não nos filhos dos outros; mostra também que investem só até ao ponto em que os filhos devolvam os benefícios genéticos do investimento, reproduzindo-se por sua vez. Os conflitos entre pais e filhos resultam de diferentes interesses genéticos, em que os filhos têm interesse em manter e aumentar as taxas de investimento parental, enquanto os pais têm interesse em dividir esse investimento pelos outros filhos também. O conflito será mais visivel se os filhos forem adoptados, com aumento da probabilidade de infanticídio pelo progenitor não biológico. Como vimos mais acima, o infanticídio pela mãe biológica explica-se se o investimento materno for mais produtivo no futuro. Este é o caso em que a fêmea não possui os recursos suficientes para criar com êxito a sua cria recém-nascida, seja porque a competição inter-fêmeas é demasiado importante, seja porque os recursos são escassos; o infanticídio permite adiar o investimento materno para quando esta dispuser de condições mais favoráveis.

A teoria da selecção sexual propõe que, dadas as diferenças na fisiologia reprodutiva de machos e de fêmeas, estes apresentarão papéis reprodutivos diferentes, com as fêmeas em geral mais interessadas num maior investimento parental do que os machos, cuja paternidade pode ser manipulada pelas fêmeas. As estratégias reprodutivas de machos e de fêmeas seguem estes interesses biológicos, e as fêmeas serão, portanto, tendencialmente mais selectivas na escolha do seu parceiro, enquanto os machos estarão sobretudo interessados em fecundar mais do que uma fêmea. Na reprodução sexual, os animais podem adoptar estratégias monogâmicas, poligâmicas ou promíscuas? que serão função das relações sóciosexuais nos grupos, por sua vez adaptadas às condições ecológicas (van Hooff, 2001). A monogamia evoluiu em ecologias mais pobres, em que os esforços conjuntos dos progenitores são necessários para garantirem a sobrevivência dos filhos; na espécie humana, a monogamia floresceu em certas culturas historicamente associadas a ecologias difíceis (as zonas áridas do Médio Oriente) mas já estava esboçada ab initio em Homo por causa da neotenização do bebé humano. A imaturidade neo-natal humana necessita de uma atenção parental continuada e de uma divisão de tarefas que liberte um progenitor, geralmente a mãe, para os cuidados próximos com os filhos (Bracinha Vieira, com. pess.). A poligamia evoluiu em ecologias mais ricas, estando estreitamente associada com a dominância social. De facto, nas culturas poligínicas humanas, só 1\% dos homens tem efectivamente mais do que uma mulher (Fisher, 1994). Tanto na monogamia como na poligamia, as infidelidades tendem a acontecer e a sua função prende-se com a promoção da variedade genética e com as alianças sociais, sobretudo nas fêmeas (Ibidem).

7 Nos humanos, esta hipótese está na origem de uma compreensão genética e ecológica do comportamento egoísta e territorialmente móvel do psicopata, que é interpretado como uma estratégia de vida (life history strategy) evolutivamente estável que traz vantagens imediatas ao indivíduo (Mealey, 1995). 
O poder explicativo do modelo de Hamilton para o "altruísmo" genético não conseguiu, no entanto, resolver o problema dos comportamentos "altruístas" entre animais não aparentados. Como compreender, à luz do modelo da vantagem inclusiva, que um animal ajude ou se sacrifique por outro com o qual não tem nenhuma ligação genética? Foi Trivers quem, em 1971, ofereceu uma explicação para estes comportamentos: os genes para o comportamento "altruísta" poderão ser seleccionados se os indivíduos forem diferencialmente "altruístas" com aqueles que foram "altruístas" consigo próprios. Os morcegos-vampiro, por exemplo, partilham o alimento recolhido durante a noite com os congéneres que não tiveram oportunidade de sugar a sua própria ração de sangue. Como este comportamento é comum ao grupo, o indivíduo pode contar que, em situação análoga, será igualmente alimentado e poderá assim sobreviver. O receptor pode ser um parente, mas pode ser também um adulto não aparentado. Observou-se que os grupos de morcegos são estáveis, e que há um reconhecimento individualizado entre os seus membros, o que faz com que o receptor seja identificado e, mais tarde, solicitado por sua vez para uma dádiva de sangue. Este tipo de «altruísmo" foi chamado de "altruísmo" recíproco ou condicional e permitiu explicar uma quantidade apreciável de comportamentos cooperativos dos animais que vivem em sociedades. Foi conceptualizado em termos da teoria dos jogos e aplica métodos estatísticos à compreensão da dinâmica dos grupos. A probabilidade de ocorrência de um comportamento cooperativo variará em função da probabilidade de reencontro do mesmo animal, no futuro próximo (Axelrod, 1984). Do mesmo modo, um animal terá interesse em cooperar ou em desertar (não cooperar), em função dessa mesma probabilidade. Assim, animais solitários com alta mobilidade ecológica serão provavelmente menos cooperantes do que animais que vivem em grupos sociais estáveis. As estratégias de aviso de perigo, num grupo, que tornam o animal conspícuo aos predadores, evoluíram porque beneficiaram o grupo (Dugatkin, 1997), o que levanta interessantes questões sobre o grupo enquanto unidade selectiva na evolução. Neste caso, seria o grupo como um todo, e não o indivíduo, quem veria o seu efectivo representado na geração seguinte.

Se a vantagem inclusiva pode, na maior parte dos casos, explicar o altruísmo de grupo como um egoísmo individual, noutros casos pode ser interessante manter a hipótese da selecção de grupo. É o caso das colónias de bactérias Pseudomonas fluorescens, em que só algumas produzem um polímero que permite a sobrevivência de todas (Mirski, 2008). O conceito de selecção multinível (Sloan Wilson, 2007) aceita a existência de mais do que um nível de selecção, infra e supra-individual, e o mesmo poderá ser válido para o ser humano. Tendo em vista a importância evolutiva do polimorfismo grupal, e invertendo a perspectiva da selecção indivi-

8 A etologia europeia e japonesa, nomeadamente a primatologia, não inscrevem necessariamente as suas observações no quadro da teoria da selecção inclusiva. 
dual, poderá mesmo argumentar-se que os comportamentos de investimento na parentela correspondem a estratégias de manutenção da diversidade genética nos grupos, uma vez que são estes, como um todo, quem beneficia evolutivamente desses comportamentos, e não exclusivamente os organismos individuais.

\section{c. Psicologia evolutiva}

A psicologia evolutiva consiste na aplicação dos princípios da sociobiologia à mente humana. O termo psicologia evolutiva foi cunhado por M. Ghiselin em 1973, mas só conheceu a sua actual notoriedade a partir de 1992, com a publicação do livro The Adapted Mind. Evolutionary Psychology and the Generation of Culture, da autoria de Barkov, Cosmides e Tooby. A psicologia evolutiva tenta compreender a mente humana baseando-se na biologia evolutiva do comportamento, particularmente na sociobiologia; considera que a natureza psicológica humana é constituída por um conjunto de adaptações mentais a problemas recorrentes no Pleistoceno (150 ooo bp.) - o ambiente de adaptação evolutiva (AAE), onde ocorreu a história evolutiva recente da humanidade. Como a estrutura biopsicológica humana não mudou substancialmente desde essa época, a sua tarefa consiste em identificar as adaptações emocionais e cognitivas evoluídas nesse a mbiente, que sustentam os modos actuais de agir e de pensar dos humanos.

Baseando-se nesta ideia, os psicólogos evolucionistas John Tooby e Leda Cosmides $(1992,2002)$ propõem que a mente humana é composta por um conjunto de mecanismos funcionais que resultam da selecção natural e que estão organizados modularmente. Este módulos são «domínio-específicos» quando estão adaptados à resolução de problemas de sobrevivência e de reprodução específicos; podem também representar modos mais gerais de agir e de pensar, sendo então módulos cognitivos e emocionais «domínio-generalistas». Exemplos de módulos específicos são os que permitem a aquisição da linguagem, os que orientam as preferências sexuais, os que provocam o evitamento do incesto, os que promovem os mecanismos de ligação e as alianças sociais, os que ajudam a detectar os enganos, etc. Módulos mais generalistas são os que permitem a aprendizagem de competências sociais e cognitivas gerais.

Steven Pinker (1997, 2002), um dos representantes actuais desta corrente, considera que a psicologia evolutiva constitui um conjunto alargado de hipóteses que dão origem a um conjunto significativo de previsões testáveis sobre o comportamento

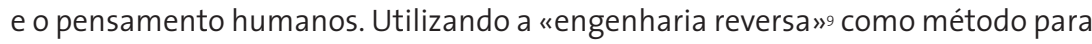

\footnotetext{
9 A engenharia reversa consiste na desmontagem dos dispositivos mentais actuais para compreender o modo como estes dispositivos evoluíram nas ecologias específicas de Homo.
} 
explicar a estrutura moderna da mente, Pinker propõe que esta se compõe de um conjunto de órgãos de computação que ajudaram os nossos antepassados a conhecer e a lidar com objectos, animais, plantas e congéneres. Partindo desta ideia, pretende explicar adaptativamente um conjunto de comportamentos e de cognições quotidianos, como as preferências perceptivas, a estrutura da linguagem, o encadeamento do raciocínio.

Os comportamentos caracterizando estes módulos e computações cerebrais derivam das observações da moderna etologia animal e humana, mas são sobretudo resultado da sua interpretação sociobiológica, onde foram compreendidos pela primeira vez no contexto da teoria da vantagem inclusiva ${ }^{\circ}$. Como vimos, esta teoria (Hamilton, 1964; Trivers, 1973; Wilson, 1975; Dawkins, 1976) defende a primazia da auto-replicação genética do indivíduo e prevê que os comportamentos sociais, assim condicionados pela maximização reprodutiva individual, dos familiares e, ultimamente, do grupo de pertença, deverão seguir vias que não contradigam o interesse genético inicial. Assim, para o altruísmo por exemplo, o indivíduo humano tenderá a beneficiar em primeiro lugar os seus filhos ou os seus parentes mais próximos, depois os parentes afastados e só no fim os que não Ihe são aparentados (Dugatkin, 1997; Lencastre, 2010), o que parece indicar a tendência nepotista da mente humana. Paralelamente, o indivíduo humano tende a desenvolver animosidade e agressividade pelos que não pertencem ao seu grupo (Eibl-Eibesfeldt, 1989).

Tendo em vista a ênfase posta sobre a reprodução enquanto critério de selecção comportamental e psicológico, não é de espantar que um dos temas preferidos da psicologia evolutiva seja a atracção, a escolha e a capacidade de manter a fidelidade do parceiro sexual. Como a propagação dos genes para as gerações futuras é a ideia-base, tanto da sociobiologia quanto da psicologia evolutiva, isto significa que a reprodução e a selecção sexual constituem elementos de particular interesse para a disciplina. A investigação nesta área baseia-se em grande parte na teoria da selecção sexual e também na teoria do investimento parental, que estabelece o grau de gastos em energia, tempo, e outros recursos, que os pais estão dispostos a ter com um filho, tendo em conta as necessidades energéticas, de tempo e de outros recursos, necessários para outros filhos e para outras actividades (geneticamente) vantajosas para si (Trivers, 1972; Clutton-Brock, 1991).

A teoria da selecção sexual prevê que o sexo que faz um maior investimento na gestação, lactação e protecção da descendência, será mais discriminativo na escolha do parceiro; o sexo que investe menos na progenitura será mais compe- 
titivo, para ter acesso ao sexo que investe mais. As diferenças sexuais relativas ao investimento parental são portanto determinantes para a selecção sexual (a escolha do parceiro e, assim, a garantia para a reprodução dos genes). As mulheres são então tipicamente o sexo que faz maior investimento parental, os machos são o sexo que faz maior investimento competitivo (no estatuto, força física, etc) de modo a atrair as mulheres.

D. Buss $(1994,2003)$ testou estas hipóteses em 37 culturas, concluindo que as preferências femininas e masculinas humanas seguem os critérios selectivos definidos pela teoria: as mulheres preferem homens com estatuto elevado e recursos, os homens preferem mulheres com sinais externos de juventude, fecundidade e saúde. As mulheres asseguram deste modo protecção para si e para os filhos, os homens garantem que o sexo será geneticamente proveitoso. Estes resultados levaram a outras previsões sobre as diferenças sexuais. No ciúme, os homens são mais ciumentos da infidelidade sexual, as mulheres são mais ciumentas da infidelidade emocional, a infidelidade masculina e feminina segue padrões diferentes que se relacionam com as diferenças nas estratégias sexuais, as mulheres procurando protecção e bons genes, os homens procurando a variedade. O divórcio ocorre com mais probabilidade quando os filhos já não necessitam do investimento paterno e quando é provável encontrar outro parceiro sexual (Fisher, 1997), as variações no ciclo ovulatório feminino acompanham-se de variações nas preferências por tipos de parceiros (Gangestad et al, 2004), a competição de esperma (Baker, 1996) aumenta as garantias de fecundação e fundamenta as ideias culturais e psicológicas sobre a anatomia masculina, etc.

Na psicologia evolutiva, a análise biológica da natureza psicológica humana segue as recomendações de Tinbergen (1963) relativamente aos factores de causalidade distantes e próximos, acima citados para a etologia. Assim, a psicologia evolutiva deverá interessar-se pela história evolutiva e adaptativa das motivações comportamentais, como também deverá debruçar-se sobre a neurofisiologia da mente e sobre os efeitos psicológicos do desenvolvimento. No entanto, a primazia que confere à interpretação adaptativa e selectiva da mente tende a produzir hipóteses neurofisiológicas pouco consentâneas com o que actualmente se sabe sobre o funcionamento do cérebro, humano e não humano (ver adiante). Ela tende igualmente a escamotear os níveis de desenvolvimento epigenéticos humanos, particularmente os culturais, na origem da diversidade bioantropológica (ver último ponto).

De facto, a grande diferença entre a psicologia evolutiva e a etologia humana, particularmente a europeia, consiste no facto da primeira condicionar a interpretação das observações e das previsões à teoria da vantagem inclusiva ou seja, ao interesse genético, que é visto como um multiplicador, aos vários níveis da 
actuação cultural (Lumsden \& Wilson, 1981). Este tipo de interpretação, que já fora duramente criticado nas primeiras tentativas de aplicar a sociobiologia ao comportamento humano (Sahlins,1976), ressurge agora em algumas das simplificações adaptacionistas da psicologia evolutiva e tem dado origem a mais do que uma crítica (Panksepp \& Panksepp, 2000; Buller, 2005), nomeadamente pela pretensão de síntese da psicologia que a disciplina apresenta. No entanto, o seu enfoque evolutivo da mente torna a psicologia evolutiva numa área de interesse actual, apresentando também valor exploratório para a psicopatologia. A visão integrada do corpo, cérebro e mente como resultando da selecção inclusiva individual, sexual e de grupo (selecção multinível, Sloan Wilson, 2007) permite avançar com hipóteses modelizáveis sobre os mecanismos mentais e as suas disfunções, que são vistos como aspectos da dinâmica sócio-sexual e ecológica dos grupos de primatas humanos e não humanos. As suas hipóteses deverão, no entanto, ser confrontadas com as observações minuciosas da primatologia e também com a psicoetologia cultural, que acrescenta os significados antropológicos às previsões comportamentais da teoria selectiva; os aspectos co-evolutivos da biologia e da cultura serão deste modo integrados numa teoria mais complexa (ver adiante).

\section{Perspectivas sobre a psicopatologia evolutiva}

\section{a. A etologia e a psicopatologia evolutiva}

Como vimos mais acima, foi com N. Tinbergen (1963) que o estudo biológico do comportamento recebeu a sua orientação programática, ainda hoje válida: qualquer comportamento, animal ou humano, deverá ser estudado segundo quatro grandes perspectivas, duas distantes e duas próximas. As perspectivas distantes interessam-se pela evolução e pela função, permitindo interrogar a história selectiva do comportamento e o tipo de adaptação ecológica e social que apresentou, e agora actualiza. As perspectivas próximas interessam-se pelo desenvolvimento, ou seja, pelo modo como a estrutura genética herdada interage epigeneticamente com factores sociais e do meio ambiente, para se actualizar através de histórias individuais concretas; interessam-se também pela causalidade imediata, que interroga os processos neuro-fisiológicos e perceptivo-motores envolvidos. Qualquer um destes níveis poderá apresentar disfunções, e qualquer um deles poderá ser considerado isolada ou integradamente, tendo em vista a disfunção em causa.

A etologia foi a primeira disciplina da biologia do comportamento a ter-se interessado pela psicopatologia humana, através da obra pioneira de Price (1967) em Inglaterra, de Desmaret (1979) na Bélgica e, em Portugal, de Bracinha Vieira (1983). Para estes autores, tratava-se de relacionar as observações da psiquiatria 
com uma teoria biopsicológica mais abrangente, que integrasse as importantes descobertas da biologia do comportamento da época, particularmente a etologia. O interesse, ainda hoje válido, destas abordagens, consiste na observação detalhada das homologias e analogias comportamentais, na sua inscrição em organizações sociais específicas e em contextos ecológicos particulares de acesso aos recursos. Com a mudança de qualquer um destes factores, mudam os comportamentos, contradizendo deste modo o determinismo atribuído à perspectiva biológica (Bussab, 1998; Sloan Wilson, 2005). Mas ao contrário da sociobiologia, que interpreta a ecologia e a genética do comportamento no contexto do modelo evolutivo da vantagem inclusiva, a etologia não aplica necessariamente um modelo selectivo transversal às espécies como, por exemplo, o modelo do investimento parental; interessa-se tanto pela convergência funcional dos comportamentos e a sua explicação por um modelo único, como pela sua diferenciação evolutiva, o que a mantém atenta às particularidades expressivas dos grupos, e ao potencial evolutivo que isso implica. Uma das suas qualidades metodológicas está em atender aos detalhes comportamentais de modo rigoroso, considerando os seus aspectos cognitivos e neurofisiológicos próprios, segundo as espécies e os indivíduos. Na etologia humana, esta particularidade permite correlacionar de modo mais realista a descrição dos comportamentos sociais com o trabalho que actualmente se realiza na área das neurociências (Panksepp \& Panksepp, 2000), e esta convergência disciplinar parece um critério robusto para avaliar o seu interesse metodológico no contexto geral da biologia do comportamento. O mesmo se aplica à compreensão das disfunções psicopatológicas.

Assim, na perspectiva da psicopatologia evolutiva baseada na etologia, a perturbação de pânico, por exemplo, poderá ser remetida à dimensão filogenética da ansiedade e/ou aos circuitos neuropsicológicos, individuais e da espécie, que estão envolvidos. Da mesma forma que a resposta imunológica evoluiu como um mecanismo regulador da homeostasia fisiológica face a um agressor, também a ansiedade e a sua expressão mais dramática, o pânico, podem ser compreendidos como respostas automáticas evoluídas do organismo face ao perigo eminente e/ou extremo (Nesse \& Williams, 1997). Uma resposta actualmente considerada como "patológica» - o pânico - é deste modo entendida segundo a sua causalidade distante: o valor selectivo que a resposta automática apresentou para o organismo que se adaptou a uma ecologia perigosa; e segundo a sua causalidade próxima: os circuitos neuro-endócrinos e psicológicos envolvidos. O mesmo raciocínio é hoje amplamente aceite na psicologia clínica de raiz evolutiva para explicar as fobias clinicamente mais significativas (Stevens \& Price, 2000).

Mas se estas perturbações da ansiedade e do pânico recebem hoje uma explicação biológica e evolutiva consensual, sendo os seus circuitos neurais bastante bem conhecidos, o mesmo não se poderá dizer de outras perturbações psicopatológi- 
cas, cuja explicação aguarda ainda por uma convergência teórica importante. É o caso da perturbação bipolar, que Demaret classificou em 1979 sob o signo dos comportamentos sociais de dominância e de submissão. Esta hipótese clínica foi posteriormente confirmada pelos trabalhos de Gilbert (1999), de Sloman \& Gilbert (2000), de Stevens \& Price (2000), de Brune (2008), de Lencastre (2009), para a depressão.

Demaret sugeriu que a componente motora e emocional dos estados depressivos poderia ser aproximada das atitudes e dos comportamentos típicos dos primatas subalternos, que se encontram face a um desafio hierárquico impossível de ganhar. A ausência de territorialidade, a perda de estatuto e o abrandamento da actividade sexual, acompanham-se de um conjunto de modificações fisiológicas e de um humor rebaixado, muito semelhantes ao que se passa com humanos em situações idênticas. A submissão e o apaziguamento são estratégias de derrota e comportamentos de de-escalada agressiva (Gilbert,1999) que apresentam um evidente valor adaptativo. A detecção da estratégia involuntária de derrota (Gilbert \& Sloman, 2000) que subentende os estados depressivos pode ajudar a perceber a situação social em que o sujeito está inserido, e a razão pela qual ele parece incapaz de se adaptar a ela conscientemente. Podem ser situações de agressão e de contestação estatutária (humilhação) continuadas na família ou noutros contextos sociais, pode ser a internalização de uma instância punitiva e de uma consequente auto-imagem negativa; os sentimentos depressivos que acompanham estas experiências remetem para situações de competição hierárquica (estatuto, reputação, auto-imagem) em que o sujeito está encerrado e das quais tem dificuldade em escapar (Desmaret, 1979; Gilbert,1999; Lencastre, 2009).

Por oposição ao estado depressivo, Demaret refere no mesmo trabalho de 1979 que a mania corresponde ao pólo positivo da disputa hierárquica: o sujeito está cheio de si, o comportamento territorial é exuberante sem que o sujeito se aperceba das suas reais limitações, os projectos são grandiosos, a sexualidade intensa. Mas a problemática do estado maníaco é a mesma do estado depressivo: trata-se de uma disputa hierárquica e de uma reclamação de estatuto e de acesso a recursos que o sujeito se acha no direito de possuir. Se, na depressão, o sentimento é o de não conseguir obter o estatuto que se pretende por incapacidade pessoal - não abandonando, no entanto, o objectivo estatutário inicial - na mania, o estatuto grandioso requerido é tacitamente assumido como próprio, e o sujeito age como tal.

Desmaret refere ainda a sazonalidade dos estados depressivos e sugere que estes poderão ser accionados por um mecanismo neurobiológico antigo, que associa a depressão ao abrandamento psicofisiológico ligado à hibernação (no outono) ou a uma sobre-estimulação hipotalâmica-hipofisária na primavera, à qual o sujeito não consegue responder. O estado depressivo surgiria de um abaixamento das 
capacidades agressivas e portanto de uma menor assertividade social, no outono, e de uma sobrecarga sentida sobre os comportamentos agressivos e sexuais, na primavera, à qual o sujeito não consegue dar resposta.

A hipótese evolutiva para a depressão e a mania sugere, portanto, que na história do indivíduo interveio um dilema estatutário e territorial importante. É sabido que a atenção ao seu lugar na hierarquia, e também ao lugar dos outros, é particularmente elevada nas pessoas com problemas de vinculação insegura (Sloman \& Atkinson, 2000), o que coincide com os dados da literatura que referem os problemas da vinculação como bons preditores para a depressão futura. De facto, uma boa vinculação garante um estado de segurança precoce que tende a perpetuar-se subjectivamente durante toda a vida (Bowlby, 1969; Fonagy et al, 2004) i.e., que protege o sujeito de um sentimento de inferioridade associado a um sentimento de exclusão, face às adversidades sociais". A intervenção terapêutica de inspiração evolutiva poderá associar a medicação com SSRI (que aumenta os níveis de serotonina etologicamente associados ao bem estar e à dominância; ver Lencastre, 2009) a uma atenção psicoterapêutica centrada sobre os conflitos e agressões estatutárias a que o sujeito esteve exposto, incluindo o seu sentimento de segurança, i. e., de ter, ou de não ter sido, protegido por figuras de vinculação. Atenderá ainda à motivação hierárquica actual do sujeito e à relação ecológica que estabelece entre a ocupação do lugar a que aspira (ou onde se encontra) e as suas formas de acesso a recursos biosociais (Gilbert, 1999; Lencastre, 2009).

Outra perturbação que, na década de 1980, recebeu uma interessante abordagem etológica é a anorexia nervosa. Esta é uma perturbação clínica resistente que tem preocupado os terapeutas devido à sua prevalência e também devido às dificuldades no seu tratamento. Uma perspectiva etológica aplicada à anorexia poderá ajudar tanto na integração funcional de alguns dos seus comportamentos aparentemente dispares identificados pela observação, como poderá contribuir para uma intervenção clínica mais eficaz.

Baseando-se na etologia dos primatas, A. Bracinha Vieira (1983) apresentou persuasivamente um modelo territorial para explicar a anorexia nervosa na jovem adolescente. Associando a maturação sexual da jovem mulher - altura em que, geralmente, as jovens fêmeas chimpanzé abandonam a associação com as mães - com a permanência da jovem humana no território familiar, mostrou a relação entre a involução reprodutiva (amenorreia e diminuição dos sinais sexuais secundários) e a recusa de alimento da anoréxica, com uma competição territorial e sexual com a mãe, impossível de ganhar. Recusar o alimento oferecido pela mãe,

11 Os factores genéticos polimórficos condicionam a ecologia da vulnerabilidade depressiva (ver Lencastre, 2009). 
numa altura em que a jovem mulher já pode prover à sua própria alimentação, significa a recusa em se subordinar ao modelo materno mas, também, em competir com a mãe dominante. Este fenómeno pode explicar os horários alimentares próprios das anoréxicas, assim como a alimentação escondida que as caracteriza. A involução dos caracteres sexuais e reprodutivos apontam para a recusa em se subordinar ao modelo de feminilidade imposto pela presença dominante da mãe, mas também a impossibilidade de impor a sua própria feminilidade reprodutiva (sexual) no território materno. Há evidência de que a involução pode resultar de um retardamento da função reprodutiva de origem social (a presença da mãe) através de mecanismos neuroendócrinos (ver adiante). A involução dos caracteres sexuais secundários corresponde a uma infantilização da jovem mulher que torna possível o convívio com a mãe ao mesmo tempo que promove uma autoimagem de prestígio, deslocada do território materno. A adolescente deslocalizada vive assim a competição sexual no território fantasiado do grupo reprodutivo alargado, evitando deste modo o papel exclusivo da "ajuda no ninho» (helper at the nest; Brune, 2008). Os dados clínicos referem nas jovens anoréxicas uma alta sensibilidade à estabilidade da família e o conflito correspondente entre dependência e autonomia'2.

Este modelo psicoetológico da anorexia nervosa implica que o tratamento recomende um afastamento do território materno e, nos casos em que a adolescente não consiga prover por si só às suas necessidades, uma maior intervenção do pai ou de outros familiares junto de quem a adolescente sinta que pode afirmar o seu território e o seu estatuto feminino próprio. É também de considerar se o fez, ou porque o não fez, naturalmente, junto do grupo de jovens pares.

Esta explicação para a anorexia nervosa associa as causas distantes com as causas próximas. As causas distantes relacionam-se com a evolução da função reprodutiva no grupo de primatas; o grupo geneticamente mais próximo dos humanos são os chimpanzés e é portanto a sua observação que nos traz mais informações sobre a evolução das relações sócio-sexuais, com traços homológicos que se manifestam também em nós. Nestes animais observa-se a emigração das jovens fêmeas, o que evita as relações de consanguinidade reprodutiva num grupo em que a paternidade é obscurecida (van Hooff, 2001). Sabe-se também que a proximidade de fêmeas de primata subalternas com fêmeas dominantes, que podem ser as mães, acciona mecanismos neuroendócrinos de retardamento ou mesmo de supressão da função reprodutiva (Abbott et al, 1998), e o mesmo parece ser verdade para os humanos (Brune, 2008). Este facto poderá mostrar a associação entre as causas distantes e as causas próximas para o aparecimento da síndrome anoréctica. De

12 A deslocalização das motivações sociais (sexuais e de estatuto) para um mundo fantasiado onde a anoréxica encontrou um lugar pode constituir uma das razões para a resistência clínica desta patologia. 
facto, sabe-se que em algumas espécies, a presença de uma fêmea dominante inibe o desenvolvimento sexual das subordinadas (Lusk \& Miller, 1989), e este efeito é provavelmente conseguido através de mensagens químicas ligadas às feromonas. A função será impedir a reprodução consanguínea ou em territórios com recursos limitados (com efeitos sobre a diminuição da competição inter-fêmeas). A mesma hipótese parece ter sido confirmada para vários grupos de primatas (Abbott et al, op. cit), o que nos fornece um mecanismo neuroendócrino próximo e uma causa funcional distante para o afastamento das jovens fêmeas do grupo familiar. Nos humanos, acresce a estes factores a ecologia cultural do ocidente, que favorece uma imagem anoréctica dominante como modelo para a jovem mulher, em busca de estatuto e de diferenciação, numa sociedade de abundância (ver Brune, 2008 para uma explicação mais detalhada deste processo; ver nota 12).

Um fenómeno relacionado com esta questão foi observado e tematizado na antropologia por C. Lévy-Strauss (1949), que identificou e descreveu o mecanismo de afastamento das jovens mulheres em muitas etnias humanas. $\mathrm{O}$ afastamento acompanha-se da exogamia, que é inserida no contexto universal da troca e da aliança entre grupos, assim aparentados. A exogamia contribui para a promoção da reciprocidade e para o abrandamento da agressão entre grupos humanos, nomeadamente na competição pelas mulheres. Os processos pelos quais estes comportamentos biosociais se transformam em normas culturais prende-se com a história própria a cada etnia considerada. Uma vez que o desenvolvimento dos indivíduos se dá no interior dos grupos culturais, é de esperar que a estrutura psicobiológica reflicta a normatividade do grupo, e vice-versa (ver adiante). A etologia cultural (Thinès, op. cit) permite fazer estas ligações e reconhecer o padrão biológico sob a diversidade das fórmulas antropológicas. A estabilização selectiva dos circuitos neuropsicológicos envolvidos nos comportamentos (Changeux, 1983) segue as vias epigenéticas próprias aos grupos culturais. Trabalhos recentes em roedores mostram que os padrões epigenéticos poderão ser transmitidas aos descendentes. De facto, segundo investigação feita em ratos, as modificações bioquímicas, fisiológicas e comportamentais poderão ser transmitidas à gerações seguintes (Hall, 2010). Isto representa um poderoso mecanismo (lamarckiano) de diferenciação e, nos humanos, de adaptação ou de disfunção biocultural (Handel, 2010). A construção do nicho humano (Laland \& Brown, 2006) através da agricultura, por exemplo, fornece mais elementos para esta diferenciação biocultural que tem recentemente contribuído para a globalização dos hábitos alimentares, paralelamente à diversificação genética por miscigenação. Este panorama terá efeitos sobre os comportamentos humanos e seus desvios. De facto, há evidência de que a dieta alimentar tem efeitos epigenéticos herdáveis que podem afectar, de modo não negligenciável, o comportamento e também a predisposição psicopatológica (McGowan, 2008). 


\section{b. A psicologia evolutiva e a psicopatologia}

A psicologia evolutiva baseia-se na hipótese de que a mente humana possui uma história evolutiva, da mesma forma que o corpo. Neste sentido, os humanos modernos estão equipados com os dispositivos adaptativos que foram seleccionados na história biológica recente da humanidade (Pleistoceno ou AAE) e a mente reflecte essas adaptações através de motivações para agir, para pensar e para sentir de determinadas maneiras (Tooby \& Cosmides, 1992; Buss, 2004). Uma análise das raízes das motivações e emoções humanas mostra que estas seguem genericamente as funções de sobrevivência e de reprodução, sendo que esta última consiste, segundo a psicologia evolutiva, no motor essencial para a organização dos comportamentos sociais (Gilbert et al, 2000) - coincidindo curiosamente, nesse aspecto, com as primeiras observações da psicanálise sobre a importância da sexualidade.

Assim, as características psicológicas dos homens e das mulheres seguem as previsões motivacionais e comportamentais genericamente atribuídas à maximização reprodutiva dos mamíferos (Buss, 1995): os homens são maiores, correm mais riscos, preocupam-se mais com a riqueza e com o estatuto, competem mais entre si, porque assim se tornam parceiros mais escolhidos pelas mulheres. Estas, por sua vez, preocupam-se com a atractividade e a juventude da aparência, correm menos riscos, competem entre si pela beleza e pela reputação, escolhem os homens pelo seu vigor (genético) e pelo seu estatuto social. Esta descrição corresponde significativamente ao que é encontrado na antropologia (Fisher, 1994) e o trabalho de Buss, acima citado, efectuado em diversas culturas (Buss, 1989), mostra que as opiniões psicológicas seguem os padrões comportamentais.

Coincidindo com as previsões da psicologia evolutiva, investigações da psicologia clínica referem que a socialidade feminina tende para as relações diádicas íntimas, enquanto os homens tendem para socializar em grupos maiores (Baumeister \& Sommer, 1997). As respostas emocionais também são diferentes: as mulheres são em geral mais expressivas e têm diferentes padrões nas respostas de conductância da pele (Kring \& Gordon, 1998). Outras diferenças relacionam-se com as ligações entre o corpo, a percepção da auto-atractividade e a auto-estima que, nas mulheres, aparecem ligados com mais frequência do que nos homens (Wade \& Cooper, 1999). Segundo Rasgon et al (2000), estas características correspondem aos diferentes interesses sociais de mulheres e de homens, decorrentes dos diferentes padrões reprodutivos femininos e masculinos.

A literatura que fala das diferenças de género na psicopatologia tende a acentuar factores relativos à prevalência, à apresentação sintomática, à patogénese, deixando muitas vezes de fora as diferenças nas respostas, por exemplo, à psicoterapia. Mas dada a estabilidade evolutiva dos padrões sócio-sexuais acima 
descritos, Rasgon e colaboradores (2000) prevêem que os problemas trazidos à psicoterapia por homens e por mulheres deverão ser diversos. Assim, as mulheres tenderão a sofrer mais com problemas ligados à atractividade física, à infertilidade, à pobreza e ao abandono, ao abuso físico, e os homens tenderão a apresentar mais problemas com a dificuldade em manter o prestígio social, com a sua perda e com o falhanço das relações profissionais e sociais. Outro trabalho sobre as diferenças de género na psicopterapia (Glantz et al 2000) aponta para um conjunto de características que são encontradas na clínica, segundo que o cliente é homem ou mulher. As mulheres têm mais facilidade em comunicar as suas emoções pela linguagem, enquanto os homens permanecem mais próximos do registo comportamental. As mulheres confiam as suas fraquezas mais facilmente e os homens, por razões que se relacionam com a protecção estatutária, têm mais dificuldade em reconhecer as suas fragilidades. A motivação para um compromisso estável com o parceiro amoroso parece também ser diferente nos homens e nas mulheres, com as mulheres mais interessadas em cultivar o laço monogâmico, sobretudo se tiverem filhos pequenos, e os homens mais relutantes em respeitar a exclusividade do vínculo amoroso. Esta conclusão é, no entanto, matizada pelos trabalhos de Davis \& Daly (1997) que mostraram que o sentido de propriedade marital dos homens é muito forte e está correlacionado com o homicídio das mulheres por ciúme sexual (ver também Buss, 2005). De facto, os homens podem ser infiéis e serem, ao mesmo tempo, extremamente ciosos da fidelidade das suas mulheres. O casamento serviria, portanto, como um controlador da paternidade, e esta hipótese converge com a tese da co-evolução entre linguagem, contrato social e grupo cooperativo (Deacon, 1997; Tomasello, 2008). Esta hipótese não aponta necessariamente para o cultivo do casamento monogâmico pelos homens, na medida em que a poligamia permite associar a diversidade das parceiras com a segurança do vínculo sexual pelo casamento - e esta é a fórmula matrimonial no maior número de culturas humanas. Mas, mesmo nestes casos, o laço monogâmico parece impor-se através de preferências por uma parceira só (Fisher, 1994).

Os conflitos nas relações sexuais também podem reflectir a variedade sócio-sexual e psicológica entre homens e mulheres: como são as mulheres quem escolhe o parceiro, elas tenderão a apreciar um prolongamento dos contacto sexuais preliminares que a informarão quanto às qualidades de fidelidade e de permanência do parceiro, enquanto os homens, menos interessados num investimento de longo prazo, tenderão a ir directos e rápidos ao assunto (Glantz et al, op cit).

A par da investigação sobre os padrões sócio-sexuais dos humanos, uma outra linha de investigação da psicologia evolutiva aplicada à psicopatologia consiste no estudo das relações familiares, tendo em conta a teoria do investimento parental e os conflitos pais-filhos (Trivers, 1974). Os humanos apresentam naturalmente 
uma socialidade afiliativa que é essencial para o bem-estar físico e emocional dos indivíduos (Panksepp, Nelson \& Bekkedal, 1997). Esta socialidade é extremamente antiga em termos evolutivos, sendo característica dos primeiros mamíferos e encontrando-se actualmente nos animais parentais e sociais. Qualquer ameaça aos laços que unem o indivíduo ao seu grupo familiar, ou ao seu grupo de pertença mais alargado, constitui um preditor de patologia mental ou física (Baumeister \& Leary, 1995). Os efeitos devastadores de uma vinculação insegura com as figuras parentais insere-se neste contexto evolutivo e pode estar na origem de disfunções fisiológicas importantes (Liotti, 2000), dificuldades em criar os próprios filhos (Hazan \& Zeitman, 1994), regulação e sentido de si deficientes (Bowlby, 1988), sistemas de significação e modelos relacionais desajustados (Simpson \& Rholes, 1998). Problemas de vinculação correlacionam-se positivamente com a possibilidade de vir a cometer incesto (Erickson, 2000), de apresentar comportamentos sexuais adultos desviantes (Stroufe \& Fleeson, 1986), de viver conflitos nas relações amorosas (Zeifman \& Hazan, 1997).

A teoria da mente mostra que a capacidade para mentalisar - compreender o comportamento em termos dos estados mentais associados, tanto em si como nos outros - capacidade essa que é essencial para a integração da experiência interna e externa, está ligada à qualidade da vinculação (Fonagy et al, 2004). Esta consiste na base segura para o desenvolvimento do sentido primário de si e dos outros (representações de primeira ordem) e também para as representações de segunda ordem (simbólicas) e para a reflexividade. Pais com sintonização emocional (tuning) com o seu bebé e com reflexividade elevada promovem mais facilmente uma vinculação segura, e a capacidade dos pais em atenderem à experiência mental dos filhos facilita a compreensão geral da sua vida mental e a dos outros (Fonagy et al, 2004). O espelhamento emocional (mirroring) das respostas dos pais são inatas e inconscientes e esta representação parental da experiência emocional da criança é mapeada, pela criança pequena, na sua constituição do estado do self. Um processo idêntico caracteriza a internalização dos estados ansiosos da mãe, pela criança em sofrimento: a vivência somato-psíquica da ansiedade é estruturada por uma mistura confusa de experiências fisiológicas, comportamentais e imagéticas, espelhadas de mãe para bebé e vice-versa. Se não houver capacidade de contenção (emocional e simbólica) da emoção do bebé, esta associação determina uma experiência mentalizada de segunda ordem que é ansiosa, e é simbolicamente representada de cada vez que uma situação idêntica é activada. Normalmente, as mães espelham a experiência do bebé mas acrescentam outros afectos como sorrir, questionar, brincar etc. A partilha de estados mentais associados à verbalização de outros afectos permite o processo de formação simbólica da experiência própria, como própria, e diferente da que é vivida pela mãe (Fonagy e tal, op. Cit.). 
Wyman \& Tomasello (2007) propõem que a capacidade dos bebés humanos para partilharem intencionalidade (estados mentais) e partilharem a atenção (seguindo o apontar do dedo, por exemplo) é possível por causa da maior cooperação e confiança no interior dos grupos altruístas. O mesmo não acontece com os chimpanzés, que carecem de atenção partilhada desta forma. É possivel que tenha havido co-evolução entre cooperação, mentalização e linguagem, nos grupos individualizados: a capacidade simbólica surgiu então associada à partilha de estados mentais (estados do mundo) em grupos em que prevalece a confiança, fundada na vinculação. Assinalar um foco de atenção pelo simples prazer de o partilhar com outro (e não por uma razão instrumental) indica um alto nível de protecção contra a competição social e, provavelmente, uma capacidade alargada para cooperar, interna aos grupos humanos individualizados (Lencastre, 2010). Em termos evolutivos, os nossos comportamentos pró-sociais desenvolveram-se integrando as nossas tendências agressivas, que são mais antigas em termos filogenéticos. Estas ligaram-se sobretudo à discriminação contra os estranhos e serviram também para a estruturação da vida social. A pressão evolutiva que seleccionou a cooperação e o altruísmo no interior dos grupos associou-se à que leva a discriminar contra aqueles que não pertencem a esse grupo e são potencialmente seus inimigos (Eibl-Eibesfeldt, 1989). Esta capacidade também se prende com a situação da vinculação.

De facto, a vinculação serve não só para ligar o bebé e a criança à figura parental protectora, mas está também na base do reconhecimento dos que pertencem à família e dos que Ihe são estranhos (Erickson, 2000). Esta capacidade, que é comum a todos os animais parentais e também a todos os animais que se ligam ao grupo por processos de imprinting (os insectos sociais, por exemplo), permite um reconhecimento imediato da parentela e a activação dos comportamentos familiares típicos, como o investimento altruísta e o evitamento do incesto (Hamilton, 1963; Smuts et al, 1987). Todos os outros animais são sujeitos a processos de avaliação de proximidade (familiaridade) e de classificação, e o mesmo se passa com os humanos (Daly \& Wilson, 1988).

O parentesco biológico é, nos humanos, alargado ao parentesco psicológico (Bailey, 2000) e o mesmo não é de excluir nos outros primatas sociais, em que se apreciam verdadeiras amizades entre os animais (Goodall, 1986 ; de Waal, 1996). Nos humanos, o parentesco psicológico permite conferir um estatuto de família às crianças adoptadas, aos cônjuges, a(o)s cunhado(a)s e a(o)s amigo(a)s. Uma classificação deste tipo alarga o círculo do investimento familiar e estabelece graus de obrigações e de expectativas tacitamente partilhadas. Há evidência, no entanto, de que os parentes extra-biológicos serão mais facilmente maltratados e até mortos (Daly, Salmon \& Wilson, 1997), sendo o não parentesco genético um preditor significativo para identificar os alvos preferenciais da violência familiar, física ou psicológica (Ibidem; Buss, 1995). 
Mesmo se a família biológica pode ocasionalmente consistir num local de elevada violência intra-familiar, na medida em que existem conflitos entre pais e filhos e entre filhos entre si (Trivers, 1974; Daly \& Wilson, 1988), é geralmente na família e nas relações precoces que se estabelecem os laços afectivos fundamentais (Bowlby, 1988; Erickson, 2000), com efeitos reconhecíveis nos comportamentos adultos e nos níveis de desenvolvimento moral (Reimer, 2005). Estes mecanismos foram adaptados a grupos individualizados, mais ou menos estáveis, e de tamanho limitado a cerca de 150 indivíduos (Dunbar, 1992) para cujo reconhecimento nós estamos naturalmente equipados. Actualmente vivemos em sociedades de milhares, ou de milhões de indivíduos, que não podemos conhecer pessoalmente e com quem nos cruzamos todos os dias, aumentado proporcionalmente os níveis de stress social relacionado com o anonimato (Eibl-Eibesfeldt, 1989). Os nossos modelos de identificação tornaram-se mediatizados e distantes, aumentando também os níveis de frustração e de agressividade interpessoal decorrentes da incapacidade óbvia em atingir os níveis de identificação exigidos pelas figurasmodelo veiculadas pelos mass-media. Particularmente preocupante nos modelos de identificação adolescentes, o problema da descoincidência (mismatch) entre aspectos da nossa estrutura evolutivamente estável e os contextos sociais expandidos da actualidade (Cosmides \& Tooby, 1992; Stevens \& Price, 2000; Brune, 2008; Lencastre, 2010) é provavelmente um dos factores mais importantes para o desenvolvimento de patologias mentais e físicas (Bailey, 2000).

A nossa tendência para nos relacionarmos intimamente com a família biológica e psicológica presente nos pequenos grupos em que evoluímos na maior parte do nosso tempo filogenético enquanto mamíferos, primatas e humanos sociais, está certamente na origem das nossas dificuldades em nos adaptarmos a contextos sociais muito diferentes. O mesmo poderá ser dito sobre os contextos ecológicos contemporâneos, cujo desajuste com a nossa psicofisiologia evoluída está na origem de patologias físicas e mentais variadas (Brune, 2008). Basta pensar na recente prevalência da diabetes nas populações indígenas da América do Norte que adoptaram o regime alimentar demasiado rico dos países desenvolvidos (Acton et al, 2002), ou nos índices crescentes de depressão nos países em vias de desenvolvimento cujas transformações sociais rápidas desorganizaram os modos tradicionais de vida familiar e comunitária.

A importância adaptativa da proximidade física e psicológica dos humanos entre si, particularmente no seio dos pequenos grupos individualizados, em ecologias específicas (Eibl-Eibesfeldt, 1989), foi paralela ao desenvolvimento de um cérebro social (Brune, Ribbert \& Schiefenhowel, 2003) orientado para a detecção de sinais sociais (Kinderman, 2003) e para a apresentação de «mentalidades sociais» (Gilbert, 2000). Estas mentalidades incluem estratégias mentais rápidas que, segundo Gilbert (2000), processam informação relativa a assuntos sociais importantes, 
como os cuidados afectuosos, a selecção de parceiro, a formação de alianças, o comportamento hierárquico, a distinção entre familiares e não familiares, etc. Algumas destas estratégias poderão estar afectadas no autismo, que parece apresentar deficiências no processamento cognitivo de faces e de direcção do olhar (Volkmar et al, 2003), na esquizofrenia que, segundo Brune (2003, 2008), apresenta déficits nos processos neocorticais de aprendizagem social, e na personalidade borderline que, para Dammann (2003) constitui um caso extremo de mentalização feminina. De facto, segundo este autor, 70-90\% dos pacientes com perturbação borderline são mulheres que apresentam níveis muito elevados de emotividade e de sensibilidade típicos dos padrões sociais femininos (dificuldade em separar-se dos problemas dos outros, irritabilidade, tendência para personalizar, tendência para adoecer fisicamente, etc; ver também Brune et al, 2010).

\section{Aspectos críticos da psicopatologia evolutiva}

\section{a. Limitações da perspectiva adaptacionista}

O pressuposto essencial da perspectiva evolutiva, tanto na etologia como na psicologia evolutiva, consiste na interpretação adaptacionista dos comportamentos e dos processos mentais. Estes são remetidos para os cenários passados em que o organismo sobreviveu e transmitiu os seus genes, e para os contextos actuais em que os exprime. Mas se a etologia animal e humana se interessa pelas semelhanças entre espécies, populações e culturas, ela também se interessa pelas diferenças que são selectivas em habitats e percursos históricos particulares, de onde emergem³. Já a psicologia evolutiva interessa-se particularmente pelas semelhanças, adoptando uma visão generalista para interpretar os comportamentos e os conteúdos mentais e aplicando os princípios da sociobiologia para fazer previsões individuais e sociais. A aceitação tácita que faz do fundamento genético-ecológico do comportamento e da organização modular da mente reserva pouco lugar para a observação das diferenças cognitivo-comportamentais, particularmente quando se trata da espécie epigenética e plástica que é a espécie humana.

Segundo Panksepp \& Panksepp (2000) um dos problemas da psicologia evolutiva consiste na aceitação massiva de adaptações cortico-cognitivas discretas (os módulos) como se fossem características de Homo, quando elas reflectem as adaptações emocionais e motivacionais mais antigas, encontradas pela etologia no grupo dos mamíferos. Ao invés de procurar o substrato neurobiológico para esses supostos módulos, a psicologia evolutiva deveria interessar-se pelas

\footnotetext{
13 D. Lestel (2001) aconselha mesmo o desenvolvimento de uma etnografia símia que permita atender às especificidades relacionais e culturais destes animais.
} 
interacções entre as zonas mais antigas do cérebro de mamífero com as zonas corticais mais evoluídas, onde se dão os processos perceptivos, associativos e cognitivo-linguísticos específicos dos humanos. Para isso, interessam tanto as semelhanças (homologias) entre as espécies próximas dos humanos, como as diferenças específicas que ilustram os caminhos evolutivos próprios. Segundo Panksepp \& Panksepp (op cit), além de não haver evidência neurobiológica para a existência destes módulos no cérebro humano, actualmente só poderá haver consenso científico de que o cérebro cognitivo dos mamíferos processa objectos e acontecimentos, passagens de tempo entre acontecimentos, a navegação no espaço e outras capacidades gerais de aquisição de recursos. As outras competências sociais deverão ser procuradas nas estruturas emocionais sub-corticais e o mesmo deverá ser feito para a espécie humana.

Assim, segundo estes mesmos autores, a evolução das competências cognitivas superiores que estão associadas à emergência do espaço cortical generalista, será melhor entendida, entre outros, como um dispositivo geral de aprendizagem e de criação (de culturas, nomeadamente) do que como um conjunto de algoritmos pré-definindo a vida social. De facto, assistimos nos humanos a uma diversidade de fórmulas antropológicas para a vida social que não parecem ser o resultado linear dos constrangimentos ecológicos passados (ou do AAE), ou até mesmo o resultado de determinismos genéticos. Mesmo se pudermos identificar corticalmente nos humanos alguns mecanismos de aquisição de recursos relacionados com necessidades sócio-emocionais específicas (como sistemas de monitorização da atractividade, da reciprocidade social, da leitura de mentes, etc), é provável que estes derivem do desenvolvimento epigenético da mente, emocional e cognitivamente equipada para a aprendizagem precoce dessas particularidades sociais e culturais (Panksepp, 2003; Lencastre, 2009). Deste modo, a perspectiva adaptacionista dura que prédefine modularmente as tendências comportamentais e mentais, é substituída por uma visão epigenética que considera as particularidades eco-culturais actuais, em interacção com as especificidades herdadas com os genes. A plasticidade do sistema genes/corpo/cérebro/mente torrna-se assim uma realidade metodológica.

Esta tem sido a perspectiva da etologia cultural (Thinès, op. cit; Lencastre, 1990, 1999, 2009) e também da psicoetologia (Ades, 1986; Bussab, 1998) que se preocupam com o modo como as tendências etológicas mais antigas interagem com os sistemas sociais e culturais, para produzirem fórmulas antropológicas e psicológicas emergentes. A selecção continua dentro das culturas, no interior dos nichos humanos (Laland et al, 2010), e não é de excluir que intervenham, neste processo, poderosas formas de modificação cultural herdáveis (acima). A selecção natural e a selecção cultural co-evoluem; a cultura pode modificar drasticamente as frequências genéticas através da modificação do nicho humano. A introdução da agricultura e da pastorícia permitiu que grupos humanos atingissem níveis 
demográficos elevados, paralelamente a modificações importantes nos genótipos e na fisiologia digestiva, como foi o caso da absorpção adulta da lactose. É provável que se tenham estabilizado mecanismos genéticos e epigenéticos ligados à aquisição e transmissão da informação cultural e que esta última repouse também sobre processos sociais mais antigos, típicos dos primatas não humanos. Este fenómeno, associado ao facto de que existe uma quantidade de variabilidade fenotípica e de estilos cognitivos que foram criados por isolamento reprodutivo (Panksepp \& Panksepp, op cit) e cultural, aponta para a importância dos processos de diferenciação, nos humanos. Por outro lado, a selecção cultural de traços fenotípicos aparentemente desvantajosos, como a transição demográfica típica da industrialização, com a respectiva diminuição de nascimentos, pode ter sido devida a factores comportamentais e culturais que levaram a que os indivíduos preferissem ganhar mais influência nas sociedades industriais (e pós-industriais), do que gastar tempo e energia na reprodução efectiva. Este "viés de prestígio» aumenta a probabilidade de que estes indivíduos sejam escolhidos como modelos culturais, integrando-os positivamente nas novas hierarquias (empresária/os, artistas, política/os, jornalistas...). Há evidência de que estas pessoas têm vidas sexuais mais intensas mas não necessariamente mais filhos. A emancipação dos mecanismos biopsicológicos próximos (Lencastre, 2010) orienta a evolução (genética) para caminhos diversos que não são linearmente deduzidos da teoria da selecção sexual e incluem elementos culturais (ideias, conhecimentos, produtos culturais...) como critérios de selecção (cultural). Os exemplos acima citados mostram a importância dos contextos para compreender os modos como as estruturas biológicas se actualizam dinamicamente e os modos como a evolução evolui ${ }^{14}$.

A patogénese mental tem sempre uma forte componente emocional e as emoções são tributárias da evolução dos mamíferos e dos primatas que nos antecederam (Maestripieri, 2003). Nesse sentido, a abordagem evolutiva das síndromes psicopatológicas é talvez a forma mais adequada de as compreender e fornece também o contexto teórico disponivel mais abrangente e explicativo. No entanto, há aspectos do funcionamento mental que ficam fora do quadro comparativo, particularmente os aspectos cognitivos ligados à aquisição do espaço cortical em Homo. Os sistemas sub-corticais do cérebro humano apresentam um conjunto muito elevado de homologias anatómicas, neuroquímicas e funcionais com o cérebro de outros mamíferos, sobretudo os primatas. Nos humanos, quando estas emoções sub-corticais são activadas em padrões comportamentais e mentais especificamente orientados (intencionalizados) para certos objectivos selectivos,

\footnotetext{
14 É possível que um viés de prestígio intervenha também na anorexia nervosa. Através da identificação a um estilo feminino prestigiado (adoptando a magreza extrema das modelos e figuras sociais da moda), a adolescente associa a incapacidade em competir com a mãe à manutenção de um estatuto elevado (idealizado, narcísico), no território materno.
} 
elas interagem com as áreas associativas multimodais do córtex para produzirem respostas culturais individualizadas e potencialmente inovadoras. Num cérebro capaz de falar, as respostas percorrem caminhos expressivos ainda mais variados, seguindo regras de construção dos discursos que modelam, descrevem ou camuflam as motivações etológicas vividas corporalmente, emprestando-lhes características narrativas, colectivas e individuais (Johnson, 1987). Na psicopatologia e na psicoterapia, este aspecto exige uma atenção particular às histórias de vida e ao modo como estas são contadas, na medida em que falam dos caminhos mentais e comportamentais pelos quais os processos biológicos mais antigos se actualizam em culturas, grupos e famílias. São estes caminhos que a psicoetologia cultural se propõe analisar e compreender.

\section{b. Psicoetologia cultural e psicopatologia: a relação entre o evitamento do incesto e o complexo de Édipo}

O evitamento do incesto é um dos exemplos que tradicionalmente opôs as concepções culturalistas à biologia. Para Freud (1913), a psicopatologia e a própria cultura reflectem esse interdito fundamental que separa o animal do humano. Lévy Strauss (1949) considera que este interdito consiste na passagem do estado de natureza ao estado de cultura, em que o contrato social, as trocas e a reciprocidade entre humanos se tornam possíveis. Estas ideias basearam-se na assumpção de que o incesto era comum entre os animais, uma visão antiga na tradição cultural ocidental que esteve na origem, entre outros, da separação ontológica entre os reinos da natureza e da cultura, com efeitos variados ao nível do pensamento e da prática (Latour, 1991; Descola, 2005; Lencastre, 2008). Freud postulou ainda que uma tendência incestuosa persiste em todos os humanos e que esta é recalcado ao longo do processo de desenvolvimento psicossexual da criança dando origem, no rapaz, ao complexo de Édipo e, na rapariga, ao complexo de Electra's. Para Freud, é a resolução, ou não, desta fase do desenvolvimento que está na origem da saúde ou da doença mental.

No entanto, a investigação etológica mostrou abundantemente que o incesto é raro entre os animais selvagens e que, nos animais parentais, existe uma adaptação específica para evitar o incesto (Smuts, 1985). Sabemos hoje que os humanos, tal como os outros animais, herdaram este mecanismo de evitamento do incesto a que se dá o nome geral de "efeito Westermarck» por ter sido enunciado, pela primeira vez, pelo antropólogo Edward Westermarck, em 1922. Este autor, que

15 É de referir que, na tradição psicanalítica, o complexo de Édipo foi em primeiro lugar descrito para o rapazinho, sendo posteriormente aplicado por analogia ao complexo de Electra, na rapariga. Neste texto iremos ocupar-nos do complexo de Édipo masculino. 
conhecia os efeitos biológicos negativos da consanguinidade, sugeriu que, nos humanos, a co-habitação em idade precoce desenvolve naturalmente uma aversão pelas relações sexuais entre os co-habitantes.

O evitamento espontâneo do incesto nos humanos foi convincentemente observado nos kibbutz em Israel (Shepher, 1971) e nos Simoua em Taiwan (Wolf, 1995). Seguindo as preferências sexuais prémaritais de adolescentes que tinham cohabitado nos kibbutz dos o aos 6 anos, Shepher observou que não houve nenhuma afiliação sexual entre eles. Por sua vez, Wolf estudou mais de 14000 casais Simpua e descobriu que a taxa de natalidade entre os Simpua que tinham co-habitado durante os 2.5 primeiros anos era extremamente baixa, o número de divórcios alto, e também era alto o número de infidelidades e de não consumação dos casamentos (Erickson, 2000). Mais importante ainda foi a descoberta de que o efeito Westermarck se desenvolve durante os 2.5 primeiros anos de vida, que correspondem ao período crítico para a vinculação, a distinção entre os familiares e os não familiares, e para a aquisição do desinteresse sexual pelos co-habitantes. Wolf descobriu ainda que se os Simpua tivessem co-habitado após os 3 anos de idade, já não mostravam claramente esse desinteresse sexual. Estes resultados indicam que o evitamento do incesto é um fenómeno biológico adaptativo que tem repercursões sobre as preferências psicológicas, e que se desenrola num espaço de tempo definido - até cerca dos 2.5 anos de idade.

Esta descoberta enfatiza um mecanismo biológico evolutivamente antigo ao invés de um processo cultural mais recente. Será que inviabiliza o complexo de Édipo tal como foi proposto por Freud?

O complexo de Édipo parece-nos mostrar com bastante clareza o modo como biologia e cultura interagem para produzirem fórmulas histórico-antropológicas e também vivências psicológicas (emocionais, cognitivas) estruturantes da individuação, no seio dessas tradições. Tomaremos a descoberta, por Freud, do complexo de Édipo, como a expressão de a) uma tradição histórico-antropológica onde se exprime a biologia do evitamento do incesto; e b) a elaboração dessa mesma tradição, no contexto da psicoterapia nascente.

Assim, analisando em detalhe a biologia do evitamento do incesto, Erickson acentua, no seu trabalho de 2000 , que as bases de reconhecimento da família se processam até aos 2.5 anos de idade, o que corresponde ao período crítico para o estabelecimento da vinculação e para o desenvolvimento dos comportamentos altruístas (seguindo o modelo da vantagem inclusiva; Trivers, 1974) ${ }^{16}$. Para este autor, os laços afectivos formados após este período crítico serão mais significativamente não familiares e provavelmente mais sexualizados. No entanto, esta 
hipótese não coincide totalmente com as observações dos comportamentos infantis humanos e com a etologia das relações mãe-juvenil nos primatas, em que o incesto adulto não se observa. Nos chimpanzés, o jovem macho que ainda se encontra junto da sua mãe reconhece os sinais sexuais quando esta está no cio e apresenta vários comportamentos de evitamento da estimulação, como afastar a face, cobrir os olhos com os braços, mostrar sinais de ansiedade, etc (Cyrulnik,1995). Esta reacção mostra que o jovem animal é sexualmente sensivel à mãe e que activa comportamentos evitativos para não se aproximar dela. Esta é também a idade em que as mães chimpanzé afastam activamente os filhos, apesar dos protestos dos juvenis (Goodall, 1986).

Nos humanos, a observação mostrou que os comportamentos sexuais infantis, como as auto-manipulações genitais, começam cerca dos seis meses de idade, nos rapazinhos, e cerca dos dez meses de idade nas raparigas, com demonstrações evidentes de prazer (Bancroft, 2009). Meninos e meninas com cerca de 15-16 meses de idade mostram comportamentos de masturbação claros e podem ocasionalmente montar objectos inanimados (Ibidem). Os 3 anos de idade correspondem ao início da socialização autónoma entre pares que, no rapazinho, inclui a exibição de um conjunto de sinais hierárquicos, agressivos e territoriais (Eibl-Eibesfeldt, 1989). Na tradição psicanalítica, Winnicott chama a esta a fase do "pavonear e armar». Os meninos descobrem a importância de serem meninos e as meninas, a importância de serem meninas. Nesta idade, o rapazinho já não se encontra exclusivamente na presença física da mãe e exercita um conjunto de comportamentos de dominância que podem incluir comportamentos sexuais como a exibição e a comparação genital, e por vezes a intenção de montar outras crianças. O comportamento de montar, que é observado nos primatas, tanto no contexto sexual como no contexto das relações de dominância e de submissão (Wickler, 1976), também está presente na espécie humana (Eibl-Eibesfeldt, 1989), podendo aparecer na linguagem (dos rapazes adolescentes, por exemplo) e podendo aparecer fantasmaticamente na clínica, sobretudo nos homens ${ }^{17}$. Assim, para além de uma sensibilidade sexual normal, tal como foi acima descrita para o jovem chimpanzé macho, também não é de excluir que a excitação pela dominância

\footnotetext{
17 A interpretação do comportamento de montar no contexto das disputas hierárquicas, nos primatas humanos e não humanos, permite a importante distinção clínica entre o comportamento de montar de dominância (ou de submissão) e o comportamento verdadeiramente homossexual. O primeiro, que a tradição psicanalítica designa de homosexualidade narcísica, relaciona-se com questões de estatuto, de identidade e de poder (questões fálicas), o segundo com questões sexuais e eróticas. Não é de excluir que haja uma forte associação psicológica entre os afectos regulando estes comportamentos diferentes, na medida em que, em termos filogenenéticos, a agressão e o estatuto surgem, nos machos promíscuos e poligínicos, estreitamente ligados à reprodução e, portanto, à sexualidade. É de notar ainda que a associação do comportamento de ser montado à submissão serve provavelmente de fundamento para a menorização, em certas culturas, dos comportamentos homossexuais passivos.
} 
se acompanhe, nos humanos como em outros primatas, de reacções sexuais precoces, sem que estas sejam preditoras de comportamento incestuoso adulto.

Voltando a Freud, Erickson (op. Cit) analisa a proposta do complexo de Édipo e a sua ligação aos 3 anos de idade, como o resultado da vivência precoce de Freud na sua família de origem. Lendo as cartas que este escreveu a Fliess, em que Freud faz grande parte da sua auto-análise, descobre-se que este tinha sido criado por uma ama durante os anos mais precoces da sua infância. O nome dessa ama era Monika Sajil e dela pouco se sabe a não ser o que o próprio Freud escreveu nas suas cartas a Fliess: que a ama foi o seu "prime originator", que era feia, velha e inteligente e que Ihe falou muito de Deus Todo Poderoso e do inferno, e que Ihe deu os meios de viver e de continuar vivendo...

Na mesma carta, Freud conta que mais tarde (entre os 2 anos e os 2.5 anos) a sua libido despertou ao ver a sua mãe despida durante uma viajem que os dois fizeram para Viena (Freud, 1985 in Erikson, 200o). Então Freud concluiu que o seu desejo pela mãe e a rivalidade que sentiu pelo pai correspondem ao núcleo emocional universal da infância, o «poder avassalador de Oedipus Rex» (ibidem). Desta história, Erickson deduz que o efeito Westermarck, no caso de Freud, fora orientado para a sua ama e não para a sua mãe. Para este autor, o facto de Freud ter sentido sensações voluptuosas observando a figura materna só prova que o rapazinho não desenvolvera o evitamento espontâneo dos desejos voluptuosos pela mãe; portanto, deduzimos que, para Freud, o interdito deveria ser ditado pela lei da cultura, ou seja pela lei patriarcal do pai.

No entanto, numa outra carta a Fliess, Freud relata um sonho com a ama em que esta Ihe ensina "coisas sexuais» (Freud, 1985 in Erickson, 2000). Pelo menos em sonho, Freud fantasia sexualmente com a sua ama; mas, ao contrário de Erickson, que propõe como explicação para este sonho'8 a hipótese de um abuso sexual precoce de Freud pela ama, podemos legitimamente pensar que o mecanismo biológico de evitamento do incesto (adulto) pode incluir sensações sexuais na pequena infância, pelo menos no chimpanzé e provavelmente no ser humano, sem que estas sejam preditivas de incesto no futuro. De facto, a observação de que nos animais há evitamento do incesto é feita quando os animais entram na fase reprodutiva e não antes, porque isso não faria sentido (Smuts, 1985; Goodall, 1986). O mesmo se passa com os humanos: foi a observação do comportamento dos antigos habitantes dos kibbutz e dos casais Simpua que, retrospectivamente, ajudou a identificar o "efeito Westermarck». Nada sabemos sobre os jogos sexuais das crianças co-habitantes, nem sobre as sensações que possam ter experimentado pelos seus pais - sem que isso tenha sido factor de incesto no futuro. Não está

18 E para a sexualidade omnipresente na obra de Freud. 
portanto excluída a possibilidade de formas precoces e saudáveis de sexualização das relações familiares, eventualmente, no rapaz, no contexto da afirmação de si, sobretudo se o grupo social acessível se compuser quase exclusivamente dos pais e dos irmãos - sem que esse facto contribua, por si só, para um aumento das relações incestuosas, no futuro.

Ao invés da explicação psicologisante que Erickson propõe para justificar a importância da sexualidade na obra de Freud e, particularmente, a identificação que fez do complexo de Édipo, nós podemos legitimamente assumir que, com este complexo, Freud trouxe à luz um núcleo organizador da cultura social, e até religiosa, da época em que viveu e que marcou (e continua a marcar) a nossa tradição ocidental.

De facto, a organização sócio-familiar burguesa do espaço doméstico, próprio das famílias da classe social em que Freud cresceu, pode ter contribuído em grande medida para estimular a curiosidade do rapaz inteligente e vivo que ele provavelmente deve ter sido. O secretismo das relações escondidas no quarto parental (que Freud referiu), associado ao patriarcado e às restrições sexuais de homens e mulheres, particularmente importante nas famílias judaicas, ajudou à identificação do complexo de Édipo (por Freud adulto): este complexo associa o evitamento adulto das relações comportamentais incestuosas com a mãe, as primeiras sensações voluptuosas e as demonstrações de dominância (e portanto de rivalidade) com os outros masculinos (incluindo o pai) na pequena infância, a procura de um lugar na hierarquia social familiar (com, finalmente, identificação ao pai). O mito grego consiste, com toda a probabilidade, na condensação original deste romance, tanto biológico como cultural.

Assim, a herança cultural de Freud, judaica e grega, importou para a identificação, como complexo de Édipo, desta dinâmica, tanto cultural, quanto psicológica e biológica'. A cultura judaica (e também judaico-cristã) tradicional assenta no respeito à lei do pai (e do Deus-Pai) ${ }^{20}$ e na punição da transgressão, particular-

\footnotetext{
19 Freud temeu que a psicanálise fosse considerada uma ciência judaica e portanto, rejeitada como não sendo uma verdadeira ciência. Mas o modo como a psicanálise se ajustou aos conflitos típicos da sociedade do tempo de Freud e, mais tarde, aos problemas psicológicos típicos da sociedade ocidental da primeira metade do sec. XX, e até mais tarde, prende-se justamente com a adequação biológica e cultural da teoria às vivências psicológicas. Podemos conjecturar que a viragem da psicanálise estruturapulsão para a psicanálise das relações de objecto (Greenberg, \& Mitchell, 1983) acompanha, também ela, uma viragem cultural e social no ocidente. De facto, a repressão das pulsões sexuais parece já não corresponder às problemáticas psicossociais dominantes na actualidade pós-moderna; estas prendem-se mais com questões da relação (de objecto), da procura identitária e da estruturação psíquica, no contexto da «modernidade líquida» (Bauman, 2000).

20 A figuração de Deus como Pai é típica da tradição judaico-cristã e greco-romana, associando-se ao patriarcado e à organização da sociedade pela lei. Outras culturas, como as culturas orientais ou as culturas de raiz hinduísta, elaboram de modo diverso a sua percepção do sagrado.
} 
mente a sexual ${ }^{21}$. Por sua vez, o rito de iniciação masculino judaico tradicional (a circuncisão)22, que significa a entrada simbólica no grupo do pai (e de Deus-Pai), pode ter sido associado por Freud ao medo da castração pelo rapazinho desobediente à lei (sexual) do pai (Deus-Pai). A interiorização da falta, por processos de mentalização típicos da tradição grega e judaico-cristã (ao contrário de outras tradições, como a africana por exemplo, em que a falta é externa - a pessoa só é culpada se for apanhada a cometer o acto proibido; de Heusch,1993), pode ter contribuído, por sua vez, para uma vivência interiorizada desta dinâmica e para o reconhecimento clínico da sua importância psicológica nas histórias de vida. Não é por acaso que a psicoterapia, enquanto prática de verbalização do mental, também nasce nesta tradição grega e judaico-cristã.

Pudemos ver como um fenómeno biológico aparece modulado por uma tradição cultural, dando origem a vivências psicológicas próprias a essa tradição. Noutras culturas, com outras organizações sócio-familiares, a etologia cultural do evitamento do incesto segue outras vias psicológicas. De facto, é bastante provável que a dinâmica de género se construa, na pequena infância, de modos muito diferentes em culturas com ecologias sócio-sexuais diferentes da ocidental. É o caso dos Deni (etnia da Rondónia, Brasil) em que à precocidade dos casamentos (cerca dos 12 anos para as meninas) se associa uma liberdade sexual muito grande desde tenra idade (com início cerca dos 7 anos) e uma grande tolerância pelas infidelidades (Lencastre, 2004). Neste povo, onde não se observa o incesto, o interdito, a falta e a punição tomam configurações muito diferentes das ocidentais. No entanto, dada a estabilidade e a intensidade emocional das primeiras relações afectivas da criança com a sua mão (características da vinculação) em todas as culturas, é provável que, quando há afastamento das crianças pequenas pela mãe (desmame, libertação sexual da mãe, nova gravidez etc), este seja vivido com alguma agitação ${ }^{23}$. É também nesta altura que a criança começa a socializar com as outras pessoas, seguindo naturalmente a organização das relações sóciofamiliares da etnia. Serão as pessoas perto da mãe quem facilitará essa separação, podendo estas ser o pai ou não24. Brown (1991) discute a questão da separação pelo pai (ou outro) a partir da polémica opondo Malinowsky e Spiro na década

\footnotetext{
21 Esta questão está particularmente bem expressa na mitologia de Totem e Tabu (1913).

$22 \mathrm{~A}$ «ferida fálica» pela circuncisão, que permite a inclusão no mundo dos homens através da submissão à lei (masculina), tem a sua origem etológica no comportamento de exibição fálica como sinal de dominância que encontramos em muitos primatas.

23 Este fenómeno também é observável nas crias de chimpanzé.

$24 \mathrm{Na}$ antropologia, as organizações sócio-familiares podem ser variadas, sendo que o núcleo permanente é o da criança pequena com a sua mãe. Encontramos numerosos relatos sobre os rituais de iniciação masculinos, no início da puberdade. É nesta idade que a separação dos rapazes do grupo das mulheres e a sua inserção no grupo dos homens é mais evidente e definitiva. As raparigas também possuem rituais iniciáticos próprios, geralmente associados à reprodução e à fecundidade (Fisher, 1994).
} 
de 1960, concluindo que, uma vez que há separação por terceiros, o complexo de Édipo é universal. Na nossa opinião, o que é universal é o evitamento do incesto e a sua inserção funcional e simbólica numa dada estrutura sócio-familiar, que inclui necessariamente terceiros com valor de referência para a criança em desenvolvimento. O Édipo descreve esta dinâmica através do complexo funcional e simbólico ocidental, marcado pelo patriarcado tradicional, a restrição sexual, a punição pela lei interiorizada, a mentalização e a falta e, mais recentemente, a ideia individualista da separação-individuação. Outras culturas colectivistas como os Deni não associam estes "valores» ao evitamento do incesto. O perigo de transportar a simbólica ocidental para fora do seu contexto corresponde ao perigo de não compreender as formas de organização comportamental e simbólica das pessoas de outras culturas. A resistência por parte de muitos antropólogos e psicólogos em aplicar o complexo de Édipo a outras culturas (e até a situações da nossa) radica nesta questão.

A psicopatologia e a psicoterapia evolutivas deverão levar em conta estas modulações culturais, na medida em que é através delas que se dão os significados psicológicos vividos pelos sujeitos. Cada cultura tem a sua forma particular de organizar as tendências biológicas mais antigas e cada cultura decide quais os comportamentos que deverão ser considerados, ou não, como normais. A perspectiva biológica sobre a psicopatologia e sobre a clínica será assim, também, uma perspectiva etnológica, sobretudo na intervenção, que lida directamente com a organização dos significados subjectivos. Por exemplo, a nossa tradição grega e judaico-cristã enfatiza a mentalização, o discurso racional e os conflitos entre a natureza (o corpo) e a cultura (o espírito). Foi nesta tradição que a psicologia clínica apontou para o carácter turbulento das relações entre as pulsões biológicas e as normas culturais, e foi também nesta cultura que a palavra apareceu como possibilidade (cultural) para resolver e libertar deste conflito. Outras culturas apresentam a questão do corpo e do espírito de modo diverso (Descola, 2005) e são também diversos os caminhos mentais que levam até à saúde ou até à doença e cura da mente (Gielen et al, 2004) A abordagem biológica da psicologia clínica é assim, também e obrigatoriamente, uma abordagem cultural.

\section{Referências bibliográficas}

Abbott, D. H., Saltzman, W., Schultz-Darken, N. J., \& Tannenbaum, P. L. (1998). “Adaptations to Subordinate Status in Female Marmoset Monkeys". Comparative Biochemistry and Physiology, 119, 261-274.

Acton, K.J., Burrows, N.R., Moore, K., Querec, L., Geiss, L.S. \& Engelgau, M. (2002). “Trends in Diabetes Prevalence Among American Indian and Alaska Native Children, Adolescents, and Young Adults". American Journal of Public Health, 92, 9, 1485-1490 
Ades, C. (1986). "Uma perspectiva psicoetológica para o estudo do comportamento animal”. Bol. psicol.36(85):20-30.g

Axelrod, R. (1984). The Evolution of Cooperation. Basic Books.

Bailey, K.G. (2000). "Evolution, kinship, and psychotherapy: promoting psychological health through human relationships". In Gilbert, P. \& Bailey, K.G. (Edts.), Genes on the couch. Explorations in evolutionary psychotherapy, USA: Brunner-Routledge, 42-67.

Baines, M.G., Haddad, E.K., Pomerantz, D.K. \& Duclos, A.J. (1994). "Effects of sensory stimuli on the incidence of fetal resorption in amurine model of spontaneous abortion". Journal of Reproduction and Fertility, 102, 221-228.

Baker, R. (1996) Sperm Wars: The Science of Sex. New York: Basic Books.

Bancroft, J. (2009). Human sexuality and its problems. UK: Elsevier Lda.

Barkow, J., Cosmides, L. \& Tooby, J., (Eds) (1992). The Adapted Mind: Evolutionary psychology and the generation of culture. NY: Oxford University Press.

Barton R.A.(1996). "Neocortex size and behavioural ecology in primates". Proc. R. Soc. B., 263,173-177.

Bauman, Z. (2000). Liquid modernity. Oxford: Polity Press.

Baumeister, R.F. \& Leary, M.R. (1995). "The need to belong. Desire for interpersonal attachment as a fundamental human motivation". Psychological Bulletin, 117, 497-529.

Baumeister, R. F. \& Sommer, K. L. (1997). "What do men want? Gender differences and two spheres of belongingness: Comment on Cross and Madison 1997". Psychological Bulletin, 122, 38-44.

Bekoff, M. \& Jamieson, D. (Edts.) (1996). Readings in animal cognition. USA: MIT Press.

Bowlby J (1969). Attachment. Attachment and Loss. Vol. I. London: Hogart.

Bowlby, J. (1988). A secure base. Parent-child attachment and healthy human development. NY: Basic Books.

Bracinha Vieira, A (1983). Etologia e Ciências Humanas. Lisboa: IN / CM.

Brown, D.E. (1991). Human universals. USA: McGraw-Hill, Inc.

Brune, M., Ribbert, H. \& Schiefenhovel, W. (Edts.) (2003). The social brain. Evolution and pathology. UK: Wiley Ed.

Brune, M. (2008) Textbook of Evolutionary Psychiatry: The origins of psychopathology. Oxford; New York: Oxford University Press

Brune, M., Ghiassi, V. \& Ribbert, H. (2010). "Does borderline personality disorder reflect the pathological extreme of an adaptive reproductive strategy? Insights and hypothesis from evolutionary life-history theory". Clinical Neuropsychiatry, 7, 1, 3-9.

Buller, D.J. (2005). Adapting minds. Cambridge MA: MIT Press.

Busnel, R.G. ( Ed.) (1962). Acoustic behavior of animals. NY:Elsevier.

Buss, D. M. (1989). "Sex differences in human mate preferences: Evolutionary hypotheses tested in 37 cultures". Behavioral \& Brain Sciences, 12, 1-49.

Buss, D. M. (1994/2003). The evolution of desire: Strategies of human mating. New York: Basic Books.

Buss, D.M. (1995). "Psychological sex differences. Origins through sexual selection”. American Psychologist, 50(30), 164-171

Buss, D. M. (2004). Evolutionary psychology: the new science of the mind. Boston: Pearson. Buss, D. M. (2005). The Murderer Next Door: Why the Mind Is Designed to Kill. Penguin Press.

Bussab, V.S.R. (1998). Uma abordagem psicoetológica do comportamento materno. In Paranhos da Costa, M.J.R. \& Cromberg, V.U. (Orgs.), Comportamento materno em mamiferos. Jaboticabal - Universidade Estadual Paulista: Soc. Brasileira de Etologia, 17-30. 
Bussab, V.S.R. \& Ribeiro, F.L. (1998). Biologicamente cultural. In Souza, L., Freitas, M.F.Q. \& Rodrigues, M.M.P. (Orgs.), Psicologia - Reflexões (im)pertinentes. S. Paulo: Casa do Psicólogo, 175-194.

Bu"tend"k, F.J.J. (1958). Mensch und Tier. Ein Beitrag zur vergleichenden Psychologie. Reinbek bei Hamburg: Rowohlts deutsche Enzyklopädie.

Camhi, J.M. (1984). Neuroethology. Massachusetts: Sinauer Sunderland.

Campbell, D. T. (1987). Selection theory and the sociology of scientific validity. In Callebaut, W. G.\& Pinxten, R. (Eds), Evolutionary epistemology: A multiparadigm program. Dordrecht: D. Reidel, 139-58.

Campbell, D. T. (1988). Descriptive epistemology: psychological, sociological, and evolutionary. In D. T. Campbell (Ed.), Methodology and epistemology for social science: Selected papers. Chicago, IL: University of Chicago Press, 435-86.

Changeux, J.P.. (1983). L'homme neuronal. Fayard:Paris.

Cosmides, L., \& Tooby, J. (2002). Unraveling the enigma of human intelligence: Evolutionary psychology and the multimodular mind. In R. J. Sternberg \& J. C. Kaufman (Eds.), The evolution of intelligence. NJ: Erlbaum, 145-198.

Clutton-Brock, T.H. 1991. The Evolution of Parental Care. NJ: Princeton U. Press.

Cyrulnik, B. (1995). Nutrir os afectos. Lisboa: Insto Piaget.

Davis JN, Daly M (1997). "Evolutionary theory and the human family." Quarterly Review of Biology 72: 407-435.

Daly, M. \& Wilson, M. (1988). Homocide. NY: Aldine de Gruyter.

Daly, M., Salmon, C. \& Wilson, M. (1997). Kinship: the conceptual hole in psychological studies of social cognition and close relationships. In Simpson, J.A. \& Kenrick, D.T. (Edts.), Evolutionary social psychology, NJ: Lawrence Earlbaum Ess. Inc., 265-96.

Dammann, G. (2003). Borderline personality disorder and theory of mind: an evolutionary perspective. In Brune, M., Ribbert, H. \& Schiefenhovel, W. (Edts.) The social brain. Evolution and pathology. UK: Wiley Ed., 373-417.

Darwin, C.R. (1859). On the Origin of Species by Means of Natural Selection, or the Preservation of Favoured Races in the Struggle for Life. London: John Murray.

Darwin, C R. (1872). The expression of the emotions in man and animals. London: John Murray. Dawkins, R. (1976). The selfish gene. NY: Oxford University Press.

Deacon, T. W. (1997). The symbolic species: the co-evolution of language and the brain. New York: W.W. Norton.

Demaret, A. (1979). Éthologie et psychiatrie. Brux.: Mardaga Ed.

Descola, P. (2005). Par-delà nature et culture. Paris: Gallimard.

Dugatkin, L.A. (1997). Cooperation among animals An evolutionary perspective. Oxford University Press.

Dunbar R.I.M. (1992). "Neocortex size as a constraint on group size in primates". J. Hum. Evol., 20, 469-493.

Dunbar, R.I.M. (1996). Grooming, gossip and the evolution of language. London: Faber and Faber.

Eibl-Eibesfeldt, I. (1970). Ethology. The Biology of Behavior. London: Holt- Rinehart e Winston Inc. Eibl-Eibesfeldt, I. (1989). Human Ethology. NY: Aldine de Gruyter.

Erickson, M.T. (2000). The evolution of incest avoidance: Oedipus and the psychopathology of kinship. In Gilbert, P. \& Bailey, K.G. (Edts.), Genes on the couch. Explorations in evolutionary psychotherapy, USA: Brunner-Routledge, 222-231. 
Fisher, H. (1994). Anatomia do amor. A história natural da monogamia, do adultério e do divórcio. Lisboa: D. Quixote.

Fonagy, P., Gergely, G., Jurist, E. \& Target, M. (2004). Affect regulation, mentalization and the development of the self. NY: Other Press.

Freud, S. (1913). Totem und Tabu. Einige Übereinstimmungen im Seelenleben der Wilden und der Neurotiker. Leipzig und Wien: H. Heller \& Cie.

Freud, S. (1985). The complete letters of Sigmund Freud to Wilhelm Fliess 1887-1904. Cambridge, M.A.: Belknap Press.

Gangestad, S. W., Simpson, J.A., Cousins, A.J., Garver-Apgar, C.E. \& Christensen, P.N. (2004). "Women's Preferences for Male Behavioral Displays across the Menstrual Cycle". Psychological Science, 15, 203-207.

Ghazanfar, A.A. \& Hauser, M.D. (1999). "The neuroethology of primate vocal communication: substrates for the evolution of speech”. Trends in Cognitive Sciences, 3-10, 377-384.

Ghiselin M.T. (1973). "Darwin and Evolutionary Psychology: Darwin initiated a radically new way of studying behavior". Science, 179 (4077): 964-968.

Gielen, U.P., Fish, J.M. \& Draguns, J.G. (2004). Handbook of culture, therapy and healing. NJ: Lawrence Earlbaum Ass. Publ.

Gilbert, P. (1999). Depression. The evolution of powerlessness. UK: Psychology Press.

Gilbert, P. \& Bailey, K. (Edts.) (2000). Genes on the couch. Explorations in evolutionary psychotherapy. UK: Brunner-Routledge

Glantz, K. \& Moehl, M.B. (2000). Reluctant males: evolutionary perspectives on male psychology in couples therapy. In Gilbert, P. \& Bailey, K.G. (Edts.), Genes on the couch. Explorations in evolutionary psychotherapy, USA: Brunner-Routledge, 176-194.

Goodall, J. (1971). In the shadow of man. Boston: Houghton Mifflin Publishing.

Goodall, J. (1986). The chimpanzees of Gombe. Boston: Houghton Mifflin Publishing.

Goodall, J. (1990). Through a Window: My Thirty Years with the Chimpanzees of Gombe. Boston: Houghton Mifflin Co.

Greenber, J.R. \& Mitchell, S.A. (1983). Object relations in psychoanalytic theory. Harvard University Press.g

Hamilton, W. D. (1963). "The evolution of altruistic behavior". American Naturalist 97, 354-356.

Hall, S. S. (2010). "Revolution postponed". Scientific American, 308, 4, 42-49.

Handel, A.E. \& Ramagopalan, S.V. (2010). Is lamarckian evolution relevant to medicine? BMC Medical Genetics, 11, 73, 10.1186/1471-2350-11-73.

Harlow, H.F. (1958). "The nature of love". American Psychologist, 13, 573-685.

Harlow, H.F., Dodsworth, R.O. \& Harlow, M.K.. (1965). "Total social isolation in monkeys". Proc Natl Acad Sci U S A.

Hazan, C. \& Zeifman, D. (1994). "Sex and the psychological tether," Advances in Personal Relationships, 5, 151-77.

Heusch, L. de (1993). La pitié et la honte. In Thinès (Ed.) Évolution biologique et comportement éthique, Brux.:Acadámie Royale de Belgique.

Hinde, R.A. (1970). Animal behaviour. AsSynthesis of ethology and comparative psychology. NY: McGraw-Hill .

Hinde, R.A. (1991). "A biologist looks at anthropology". Man, 26, 583-608.

Holst E von (1969). Zur Verhaltensphysiologie bei Tieren und Menschen. Gesammelte Abhandlungen, Bd. I., Munich: Piper. 
Hooff, J.A.R.A.M. van (2001). Vivre en groupe: entre contraintes socials, sexuelles et écologiques. In Picq, P. \& Coppens, Y. (Dir.), Aux origins de l'humanité, Paris: Fayard, 208-243.

Huxley, J. (1914). "The courtship habits of the Great Crested Grebe (Podiceps cristatus) together with a discussion of the evolution of courtship in birds". Journal of the Linnean Society of London, Zoology 53, 253-292.

Huxley, J. (Org.) (1966). "A discussion on ritualization of behaviour in animals and man". Philosophical Transactions of the Royal Society of London, ser. B, 772, 251, 247-271.

Johnson, $M$ (1987). The body in the mind: the bodily basis of imagination, reason and meaning. Chicago: Chic. Un. Press.

Jung, C G. (2002). O homem e seus simbolos. RJ: Ed. Nova Fronteira

Kinderman, P. (2003). Social cognition in paranoia and bipolar affective disorder. In Brune, M., Ribbert, H. \& Schiefenhovel, W. (Edts.), The social brain. Evolution and pathology. UK: Wiley Ed.

Klopfer, P. H. (1966). Habitats and territories, a study of the use of space by animals. NY: Basic Books.

Kring, A. M., \& Gordon, A. H. (1998). "Sex differences in emotion: Expression, experience, and physiology." Journal of Personality and Social Psychology, 74, 686-703.

Laland, K.N. \& Brown, G.R. (2006). "Niche construction, human behavior, and the adaptive lag hypothesis". Evolutionary Anthropology, 15, 95-104.

Laland, K.L, Odling-Smee, J. \& Myles, S. (2010). "How culture shaped the human genome: bringing genetics and the human sciences together". Nature Reviews, Genetics, 11, 137-149.

Latour, B. (1991). Nous n'avons jamais été modernes. Essai d'anthropologie symétrique. Paris: La Découverte.

Lencastre, M.P.A. (1990). Épistémologie évolutive et theéorie de l'emergence: contribution à une perspective fondamentale en biologie du comportement, PhD, Univ. Cath. Louvain: LLN, Belgique.

Lencastre, M.P.A.(1999). Epistemologia evolutiva e teoria da emergência: contribuição para uma perspectiva fundamental em biologia do comportamento, Colecção Textos Universitários em Ciências Sociais, Lisboa: Fundação Calouste Gulbenkian (texto traduzido, revisto e aumentado).

Lencastre, P. (2004) Viagem e estadia nos Deni, Rondónia, Amazónis in http://marlencastre. blogspot.com/

Lencastre, M.P.A. (2007). "Do corpo e da linguagem: ligações entre biologia do comportamento e psicanálise”. Revista Psychologica, 44, 377-399.

Lencastre, M.P.A. (2008). "Transdisciplinaridade e boa ciência. O contributo de Bruno Latour para a compreensão das relações entre ciência, conhecimento e sociedade". Revista de Investigação Educacional, 7, 145-155.

Lencastre, M.P.A. (2009). Corpo, Mente e Espírito. Temas Interdisciplinares de Etologia, Psicologia e Antropologia, Porto: SPAE.

Lencastre, M.P.A (2009). "Etologia da depressão. Contribuição para uma perspectiva evolutiva das emoções sociais e da depressão". Revista de Saúde Mental, XI, 4, 11-24.

Lencastre, M.P.A. (2010) "Bondade, altruísmo e cooperação. Considerações evolutivas para a educação e a ética ambiental". Revista Lusófona de Educação, 15, 113-124

Lestel, D. (2001). Sommes-nous assez intelligents pour comprendre l'intelligence des singes? In Picq, P. \& Coppens, Y. (Dir.) Aux origins de l'humanité, Paris: Fayard, 332-368. 
Lestel, D. (2004). Civilisations et mondialisation : de l'éthologie à la prospective. In Aubert, J-E. \& Landrie, J. ( Coord.). Colloque du Centre culturel international de Cerisy, du 2 au 12 août 2003.

Levy-Straus, C. (1949). Les Structures élémentaires de la parenté. Paris: Presses Universitaires de France.

Liotti, G. (2000). Disorganised attachment, models of borderline states and evolutionary psychotherapy. In Gilbert, P. \& Bailey, K.G. (Edts.), Genes on the couch. Explorations in evolutionary psychotherapy, USA: Brunner-Routledge, 232-256.

Lorenz, K. (1963). On Aggression. San Diego: Harcourt Brace.

Lumsden, C. J. and E. O. Wilson. 1981. Genes, Mind, and Culture: The Coevolutionary Process. Cambridge, Massachusetts: Harvard University Press.

Lusk, S.J.G. \& Millar, J.S. (1989) "Reproductive inhibition in a short-season population of Peromyscus maniculatus". J. Anim. Ecol. 58, 329-341.

McGowan, P.O., Meaney, M.J. \& Szyf, M. (2008). "Diet and the epigenetic (re)programming of phenotypic differences in behavior". Brain Research, 1237, 12-24.

Maestripieri, M. (Ed.) (2003). Primate psychology. UK: Harvard Un. Press.

Mealey, L. (1995). “The sociobiology of sociopathy: an integrated evolutionary model.” Behavioral \& Brain Sciences. 18, 523-599.

Mirsky, S. (2008). "Individual versus group in natural selection Does natural selection drive evolution at levels higher than selfish genes and fertile individuals?" Scientific American, 18

Moss, C. F. \& Shettleworth, S. J. (Edts.) (1996). Neuroethological studies of cognitive and perceptual processes. USA: Westview Press.

Moyer, K.E. (1968). "Kinds of aggression and their physiological basis". Commun Behav Biol. 2, 6587 .

Nesse, R. \& Williams, G. (1997). Are mental disorders diseases? In Baron-Cohen, S. (Ed.), The maladapted mind. Classic readings in evolutionary psychopathology, USA: Psychology Press.

Panksepp, J., Nelson, E. \& Bekkedal, M. (1997). Brain systems for the mediation of social separation-distress and social-reward. Evolutionary antecedents and neuropeptide intermediaries. In Carter, C.S., Lederhendler, I. \& Kirkpatrick, B. (Edts.), The integrative neurobiology of affiliation, NY: New York Academy of Sciences, 78-100.

Panksepp J. \& Panksepp, J.B. (2000). "The seven sins of evolutionary psychology". Evolution and Cognition, 6: 108-131.

Panksepp, J. (2003). "At the interface between the affective, behavioral and cognitive neurosciences: Decoding the emotional feelings of the brain". Brain and Cognition. 52, 4-14.

Pinker, S. (1997). How the mind works. NY: Norton.

Pinker, S. (2002). The blank slate: the modern denial of human nature. N.Y: Viking.

Platt, M. \& Ghazanfar, A. ( Edts.), (2010). Primate Neuroethology. Oxford University Press

Price, J.S. (1967). "Hypothesis: the dominance hierarchy and the evolution of mental illness". Lancet, 2, 243-246.

Rasgon, N., McGuire, M.T \& Troisi, A. (2000). Gender and psychotherapy. An evolutionary perspective. In Gilbert, P. \& Bailey, K.G. (Edts.), Genes on the couch. Explorations in evolutionary psychotherapy, USA: Brunner-Routledge, 196-208.

Reimer, K. (2005). "Revisiting Moral Attachment: Comment on Identity and Motivation". Human Development, 48, 262-266. 
Ristau, C.A. (Ed.) (1991). Cognitive etology. The minds of other animals. Essays in honor of D.R. Griffin. N.J.: Lawrence Erlbaum Ass. Inc. Publ.

Sahlins, M. (1976). The use and abuse of biology: an anthropological critique of sociobiology. USA: University of Michigan Press, Ann Arbor.

Schjelderup-Ebbe, T. (1922). "Beiträge zur Sozialpsychologie des Haushuhns". Zeitschrift für Psychologie 88,225-252.

Shepher, J. (1971). "Mate selection among second generation kibbutz adolescents and adults: incest avoidance and negative imprinting". Archives of Sexual Behavior, 1, 293-307.

Simpson, J.A. \& Rholes, W.S. (1998). Attachment theory and close relationships. NY: Guilford Sloman, L. \& Atkinson, L. (2000). Social competition and attachment. In Sloman, L. \& Gilbert, P. (Edts.), Subordination and defeat. An evolutionary approach to mood disorders and their therapy, USA: Lawrence Erlbaum.

Sloman, L. \& Gilbert, P. Edts. (2000) Subordination and defeat. An evolutionary approach to mood disorders and their therapy, USA: Lawrence Erlbaum.

Smuts, B.B. (1985). Sex and Friendship in Baboons. NY: Aldine de Gruyter.

Smuts B.B, Cheney D.L, Seyfarth R.M, Wrangham R.W \& Struhsaker T.T (Edts.) (1987). Primate societies. University of Chicago Press.

Stevens, A \& Price, J. (2000). Evolutionary Psychiatry. A New Beginning. London: Routledge.

Stevens, A. (2002). Archetype Revisited: An Updated Natural History of the Self. London: Routledge Ed.

Stroufe, A. \& Fleeson, J. (1986). Attachment and the construction of relationships. In Hartup, W. \& Rubin, Z. (Edts.), Relationships and development, Hilsdale, NJ: Lawrence Earlbaum Ass. Inc., 51-71.

Thines, G. (1966). Psychologie des animaux. Dessart, Brüssel.

Thinès, G. (1975). Dictionnaire général des sciences humaines. Paris: Éditions universitaires.

Thinès, G. (1977). Phenomenology and the sciences of behavior. London: Allen and Unwin.

Thinès, G. (1991). Existence et subjectivité, Brxl: Éditions de l'Université de Bruxelles,

Tinbergen, N. (1963). "On Aims and Methods in Ethology". Zeitschrift für Tierpsychologie, 20, 410-433.

Tomasello, M (1999). The cultural origins of human cognition. Harvard University Press.

Tomasello, M (2003). Constructing a language: a usage-based theory of language acquisition, Harvard University Press.

Tomasello, M. (2008).. Origins of human communication. Cambridge, MA: The MIT Press.

Tooby, J. \& Cosmides, L. 1992. The psychological foundations of culture. In Barkow, J., Cosmides, L. \& Tooby, J. (Edts.), The adapted mind: evolutionary psychology and the generation of culture. NY: Oxford University Press,19-136.

Trivers, R.L. (1971). "The evolution of reciprocal altruism". The Quarterly Review of Biology, 46-1, 35-57.

Trivers, R. L. (1972). Parental investment and sexual selection. In Campbell, B. (Ed.), Sexual selection and the descent of man, 1871-1971, 136-179.

Trivers, R. L. (1974). "Parent-offspring conflict”. American Zoologist, 14, 249-264.

Volkmar, F.R., Klin, A., Schultz, R.T,Chawarska, K. \& Jones, W. (2003). The social brain in autism. In Brune, M., Ribbert, H. \& Schiefenhovel, W. (Edts.), The social brain. Evolution and pathology. UK: Wiley Ed., 167-195.

Waal, F. de (1982)., Chimpanzee politics: power and sex among apes. London: Jonathan Cape. 
Waal, F. de (1996). Good natured: the origins of right and wrong in humans and other animals. Cambridge and London: Harvard University Press.

Waal, F. de (2006). Primates and Philosophers. How Morality Evolved. USA: University Press of CA.

Waal, F. de (1995). "Bonobo Sex and Society The behavior of a close relative challenges assumptions about male supremacy in human evolution". Scientific American, $272,3,82-88$.

Waal, F. de (2008). "Putting the altruism back into altruism: the evolution of empathy". Annual Review of Psychology, Vol. 59: 279-300.

Wade, T.J. \& Cooper, M. (1999). "Sex differences in the links between attractiveness, selfesteem and the body". Personality and Individual Differences, 29, 1047-56.

Webster, R. (2002). Freud estava errado. Porquê? Pecado, ciência e psicanálise. Porto: Campo das Letras.

Westermarck, E.A. (1922). The History of Human Marriage. Vol. I.. New York: The Allerton Book Company.

Byrne R. \& Whiten A. (Eds.) (1988). Machiavellian intelligence. Oxford: Clarendon Press.

Whiten, A. \& Byrne, R.W. (Eds.). (1997). Machiavellian Intelligence Il. Cambridge University Press.

Wickler, W. (1976). As leis naturais do casamento. Lisboa: Publ. Europa-América.

Wible, C.G., Preus, A.P. \& Hashimoto, R. (2009). "A cognitive neuroscience view of schizophrenic symptoms: abnormal activation of a system for social perception and communication". Brain Imaging Behav., 1; 3(1), 85-110.

Wilson, E.o.(1975). Sociobiology: The New Synthesis. Cambridge: Harvard University Press.

Wilson, D. S. (2005). Evolutionary social constructivism. In Gottschall, J. \& Wilson, D.S. (Edts.), The literary animal. USA: Northwestern University Press.

Wilson, D. S. (2007). Evolution for Everyone: How Darwin's Theory Can Change the Way We Think About Our Lives. New York, NY: Delacorte Press.

Wilson, D.S. \& Wilson, E.O. (2008). "Evolution "for the good of the group". American Scientist, 96(5), 380-389.

Wilson, D.R. (2006). "Evolutionary epidemiology. a bridge from ethology to genomics" comunicação no Seminário Internacional Can Ethology Meet Psychatric Expectations? In Search of a Model for Depression, Bélgica: Fond Jean-Marie Delwart.

Wolf, A.P. (1995). Sexual attraction and childhood association: a Chinese brief for Edward Westermarck., Stanford: Stanford Un. Press.

Wrangham, R. (2009). Catching Fire: How Cooking Made Us Human. Basic Books.

Zeifman, D. \& Hazan, C. (1997). Attachment: the bond in pair-bonds. In Simpson, J.A. \& Kenrick, D.T. (Edts.), Evolutionary social psychology. NJ: Lawrence Earlbaum Ess. Inc., 237-63.

Zupanc, G.K.H. (2004). Behavioral neurobiology, an integrative approach. NY: Oxford University Press. 


\section{Ethology and evolutionary psychology applying evolutionary theory to clinical psychology}

Applying evolutionary theory to behavior and mental life allows a deeper understanding and a better integration of their normal and pathological functions. This paper presents some critical aspects of cultural ethology and evolutionary psychology that converge to a wider and more articulated appreciation of psychopathology and clinical psychology. Incest avoidance is analysed both in its biological, cultural, social and psychological dimensions.

KEY-WORDS: Evolution, Cultural ethology, Evolutionary psychology, Psychopathology, Limits of adaptation.

Éthologie et psychologie évolutive vers une perspective évolutive de la psychologie clinique

L'application de la perspective évolutive au comportement et au fonctionnement mental ouvre la voie à une plus profonde compréhension et intégration de leurs aspects normaux et pathologiques. L'article présente les résultats de l'éthologie culturelle et de la psychologie évolutive, qui permettent une appréciation plus ample et plus fondée des syndromes psychopathologiques et de la psychologie clinique. L'évitement de l'inceste est analisé à partir de ses dimensions biologiques, culturelles, sociales et psychologiques.

MOTS-CLÉS: évolution, éthologie culturelle, psychologie évolutive, psychopathologie, limites de l'adaptation. 